\title{
Occurrences of Polar Pesticide Contamination in Niger River Valley and Its Tributary the Mekrou River, Using POCIS Passive Samplers and Survey of Agricultural Practices (Niger Republic)
}

Oumar El Farouk MAMAN ILLATOU ( $\triangle$ oumarel_farouk@yahoo.fr )

IMT Mines Alès: Institut Mines-Telecom Mines Ales https://orcid.org/0000-0002-7410-1125

Catherine GONZALES

IMT Mines Alès: Institut Mines-Telecom Mines Ales

Marc VINCHES

IMT Mines Alès: Institut Mines-Telecom Mines Ales

\section{Research Article}

Keywords: Agriculture, Niger River Valley, Mékrou River, Pesticides, POCIS, Ecological Risque

Posted Date: October 26th, 2021

DOl: https://doi.org/10.21203/rs.3.rs-965482/v1

License: (1) This work is licensed under a Creative Commons Attribution 4.0 International License. Read Full License 


\section{Abstract}

The increase in food needs due to high population growth in Niger has led to the intensification of urban agriculture and increased use of pesticides. The objective of this study is to assess the polar pesticide contamination of the Niger River and its tributary, the Mekrou River, in Niger, using both grab sampling and POCIS (Polar Organic Chemical Integrative Samplers) and evaluate their ecological risks in the waters. Two water sampling campaigns were carried out during the rainy and dry seasons. The samples were analyzed by liquid chromatography coupled with mass spectrometry (HPLC/MS) and allowed the detection of compounds with concentrations above the WHO guide values and the EU directive: diuron with $3281 \mathrm{ng} / \mathrm{L}$ (EU quality guideline: $200 \mathrm{ng} / \mathrm{L}$ ), atrazine with $1476 \mathrm{ng} / \mathrm{L}$ (EU quality guideline: 600 $\mathrm{ng} / \mathrm{L}$ ) and acetochlor with $255 \mathrm{ng} / \mathrm{L}$ (EU quality guideline: $100 \mathrm{ng} / \mathrm{L}$ ). Diuron and Atrazine show a high ecological risk for aquatique environment. The main source of this water contamination is the intensive use of pesticides in urban agriculture near the city of Niamey and in an intensive cotton farming in the Benin. The results of surveys showed the influence of poor pesticide application practices and seventy percent $(70 \%)$ of the pesticides used are not approved by the Interstate Committee for Drought Control in the Sahel (CILSS) and some are prohibited in Niger. These contaminations may raise concerns about the health of farmers along the Niger River and the Mekrou River.

\section{Highlights}

- The main areas of water contamination are downstream from the city of Niamey and the confluence of the river with the Mekrou River

- First state of the art of pesticides contamination of the Niger River valley

- The river Mekrou shared by Niger, Burkina and Mali is more polluted by pesticide than the Niger River due to its use in cotton production

- The high concentrations diuron and atrazine constitute a high ecological risk for aquatique environment

\section{Introduction}

The development of agricultural activities in Africa, occupies an important place for human nutrition and contributes to the national gross domestic product (GDP) of some countries. The growing demand for agricultural products, associated with yields improving involves the systematic use of chemical pesticides to control crop pests (Ahouangninou et al. 2011 ; Andres and Lebailly, 2011 ; Illyassou et al. 2015 ; Kanda et al., 2013), which consist mainly of tropical insects and parasites (Bruinsma, 2003). For African countries in the Sahelian zone that are part of the Interstate Committee for Drought Control in the Sahel (CILSS), the use of these pesticides is regulated by the Sahelian Pesticides Commitee (CSP). Several studies have shown some high concentrations of pesticides with a frequency of pyrethroids, dieldrin and organophosphate pesticides (Donald et la., 2016) in water, sediment, soil, food, air and aquatic organisms in countries concerned with the Niger River Basin including Guinea (Traoré and Haggblade, 2017), Mali (Berthe Dem et al., 2007; Le Bars et al., 2020), Burkina (Gnankiné et al., 2013; Lehmann et al., 2017, 2018; Son et al., 2017; Tarnagda et al, 2017), Benin (Okoumassoun et al., 2002; Agbohessi et al., 2011, 2012; Adechian et al., 2015; Agboyi et al., 2016, Gouda et al., 2018), Nigeria (Adeyemi et al., 2011; Ogbeide et al., 2015; Isogi et al., 2016, Ojo 2016; Gushit et al., 2017), Niger (Mamadou et al, 2005, 2008; Mamane et al.,2016; Zabeirou et al. 2018), Cameroon (Ahmadou et al., 2016 ; Norbet et al., 2017 ; Branchet et al., 2018), Côte d'Ivoire (Traoré et al., 2006 ; Doumbia and Kwadjo 2009 ; Coulibaly et al., 2012 ; Traoré A. et al., 2015) and Chad (Sougnabe et al 2010). On the Mékrou River, studies have only involved Benin part and the work has shown alarming concentrations of endosulfan (746 $\mu \mathrm{g} / \mathrm{l})$, DDT (100 $\mu \mathrm{g} / \mathrm{l})$, dieldrin $(48 \mu \mathrm{g} / \mathrm{l})$, and heptachlor in some of the waters of the W Park and the river, as well as endosulfan and lindane in fish and sediment (Elisabeth et al, 2006 ; Agbohessi et al. 2011, 2012, 2015 ; Ahouangninou et al. 2011 ,2012 ; Adechian et 
al., 2015). The W Park is a large transboundary biosphere reserve straddling Benin, Burkina, and Niger and has been listed as a Unesco World Heritage Site since 1996 and protected since 2007 by the Ramsar Convention.

In Niger, the annual population growth rate is 3.9\%, one of the highest in the world, and agriculture is the country's third largest source of income, after uranium mining and livestock. Agriculture is mainly practiced on small family farms used for food crops (millet, sorghum, cowpea and cassava), rice cultivation, and some cash crops such as corn and peanuts, without recourse to mechanization (MHELD, 2005). It is mainly practiced in the southern part of the country and along the Niger River, and corresponds to about 13\% of the national territory (Guengant and Banoin, 2003). Market garden crops such as tomatoes and onions are grown in the depressions created by ancient or recent rivers.

The Mékrou River is a temporary tributary of the right bank of the Niger River that originates in Benin in the plain west of the Atakora Mountains (Le Barbe et al., 1993; Robert Vernet, 1994). This river is heavily involved in cotton production, which began in 1965 and was encouraged by the Compagnie française pour le développement des textiles (CFDT). This production was greatly expanded in the 1980s with the large-scale application of plow-down cultivation (Leo J. De Haan, 1992). Benin is the leading cotton-producing country in Africa, ahead of Mali, Côte d'Ivoire and Burkina Faso, with production of 712,000 tons in 2020 (Benin Ministry of Agriculture), accounting for $80 \%$ of the country's export earnings (AIC, 2019).

The use of pesticides allows a good crop yield, but several works have highlighted environmental and health risks including reproductive function expectations, neurological disorders and cancerous pathologies (Multigner 2005; Ahouangninou et al. 2011; Mamane et al., 2015; Gouda et al., 2018; Le Bars et al., 2020). According to the WHO, there are approximately one million severe pesticide poisonings worldwide with some 200,000 deaths (WHO, 2006 and WHO, 2008).

Several studies in Niger have highlighted the use of pesticides and human and food exposures. The application of organophosphates, pyrethroids, and avermectins was evidenced in market garden crops of onion, cabbage, and tomato in Madaoua Department and 25 pesticide formulations, all of which were not registered by the Sahelian Pesticides Committee (Zabeirou et al. 2018). The harmful effects of chlorpyrifos ethyl and fenitrothion used against the desert locust on the two species of pimelia (Coleoptera, tenebrioniadae) in the Tafidet valley (Agadez region) and occupational exposure to organophosphates and carbamates in rural Niger were highlighted in the work of Mamadou et al., 2005, 2008. On the Niger River, the exposure of the diet of the city of Niamey to residues of phytopharmaceutical products during the hot and cold dry season was highlighted and showed that the risk of exposure was higher in children than in adults for all the residues detected and whatever the product (Massalatchi et al. 2018). These exposure risks also concern small farmers with an exposure level above the acceptable exposure level for all active substances and vary from $0.0013 \mathrm{mg} / \mathrm{kg}$ bw / day to $0.4125 \mathrm{mg} / \mathrm{kg}$ bw / day (Massalatchi et al. 2017). The result of surveys conducted on the risk of respiratory disorders in adults and children related to cultivation in Niger showed that people living in agricultural areas have an increased risk of respiratory symptoms in adults (wheezing, dyspnea, sudden shortness of breath, and cough without fever) and in children (cough without fever) compared to those in pastoral areas (Mamane et al.,2014, 2016).

Although the work carried out has highlighted the risks of exposure of certain producers through the use of pesticides, there is currently no work assessing the quality of water to pesticides along the Niger River and on the Mekrou River. Chemical pesticides are used by farmers to protect their crops from pests and are mostly exported from neighboring countries. The use of these mainly unregistered pesticides for agricultural purposes could be a source of environmental and health problems in the Niger River watershed in Niger. The objective of this study is to study the occurrences of polar pesticides contamination in the Niger River valley and its tributary, the Mekrou River, and to evaluate the inputs of pesticides from the river and its tributaries in the Niger portion of the watershed. 
The passive sampling technique will be used to detect and quantify polar compounds in the water. It has advantages in terms of the preconcentration of compounds in water and increase the possibility of detecting or even quantifying compounds present at very low concentrations in water and improving the diagnosis of contamination (Di Carro et al., 2018). Samplers will be placed along the Niger River and downstream of tributaries to accumulate molecules on a receptor phase by diffusion (mass transfer) of compounds. This technique will be used for the first time in the assessment in pesticide contamination of the Niger River and its tributaries.

\section{Materials And Methods}

\subsection{Presentation of the study area and sampling sites}

The study area is located in the Niger River watershed, in Niger, on the $550 \mathrm{~m}$, from the border with Mali in the North to the border with Benin and Nigeria in the South, and crosses the region of Tillabéry on $420 \mathrm{~km}$ and that of Dosso on 130 $\mathrm{km}$ (Figure 1). Its hydrological regime is highly variable in time and depends on the amount of rainfall in Upper Guinea and Northern Côte d'Ivoire, constituting the Guinean flood in December-January and the local flood between August and September, fed by its tributaries. It is the main watercourse in Niger and its irrigable area is estimated at 142,500 ha (SOGREAH/BRGM, 1981). Several rice schemes are located along the Niger River in both regions, covering an area of about 8,500 ha and are developed by more than 2,000 beneficiaries (Ehrnrooth et al., 2011). Several hydro-agricultural developments (AHA) have been carried out by the State of Niger over an area of 13,000 ha, the management of which was entrusted to the Office National des Aménagements Hydro-Agricoles (ONAHA), then transferred to farmers' organizations grouped into agricultural cooperatives with the objective of growing twice as much rice per year through the support of ONAHA in the framework of advice and provision of services (Baron et al., 2010).

Niger's climate is Sahelian, characterized by two seasons: a nine-month dry season (October to June) and a three-month rainy season (July to September). Niger's agro-climatic zones are made up of the Sahelo-Sudanian zone, the Sahelian zone, the Sahelo-Saharan zone and the Saharan zone. The Niger River is located in the Sahelian zone with a rainfall of between 350 and $600 \mathrm{~mm}$ per year, where agriculture is predominantly rainfed and irrigated. The Mékrou River is located in the most watered part of Niger and crosses Park W, at the common border between Niger, Benin and Burkina. It is covered by the Sahelo-Sudanese zone, which receives 600 to $800 \mathrm{~mm}$ of rainfall per year with conditions that are very favorable for rain-fed and irrigated agriculture. The latter receives about $80 \%$ of its water from Benin, which is one of the country's main cotton producing areas. The cultivable area of the zone is small so there is no agricultural activity in Park W.

\subsection{Methodology for the survey of agricultural practices and pesticide use}

Information on farming practices and pesticides used by farmers was collected from questionnaires. The representative sample of the surveyed farmer population is composed of 30 producers, mostly men, on the Liboré and Saga hydroagricultural development sites (AHA) for rice production, corresponding to sampling point F4, and the market garden sites located downstream from the city of Niamey along the Niger River. The main agricultural activities practiced along the Niger River are urban agriculture practiced by about 600 market gardeners at the Gamkalle site and the two irrigated perimeters for rice cultivation used by about 1,800 allottees in the surrounding villages. These agricultural activities are practiced for two harvests per year.

The survey questionnaire included general data on the farmer, such as level of education, age, and agricultural training received; data on the characteristics of the farm, such as the area cultivated for market gardening or irrigation, agricultural practices, and the origin of water used; and the type, frequency, and technique of chemical fertilizer and 
pesticide use. The last part of the questionnaire concerned the integration of producers in professional networks and their knowledge of the environmental issues related to the use of pesticides, as well as their opinion on the prospects for improving their activity.

The objectives of the survey were first explained to the members of the cooperative and to the producers present on the sites in order to have their involvement; and the survey was carried out with the perfect collaboration of the producers with a response rate of $100 \%$. The survey involved twenty (20) producers from the irrigated sites and ten (10) from the market gardening sites.

\subsection{Materials and method of chemical analysis of pesticides 2.4.1 Choice of sampling sites}

The preliminary study of the study area according to its size, the types of agricultural activities carried out along the Niger River, in Niger and near its tributaries made it possible to select six (6) sampling sites, five (5) of which are on the Niger River and one (1) at its confluence with the Mekrou River, in order to investigate the pesticides used and cover the entire watershed (Figure 1). Site F1 is located at the entrance of the Niger River from Mali, where there is no intense agricultural activity on the Niger side and no input from its tributaries into Niger. Point F2 is located at the confluence of the Niger River with its right bank tributary, the Sirba, where there are agricultural plots for market gardening; and upstream from the pumping stations for the water supply of the city of Niamey. Point F3 is located upstream of the city of Niamey and before the large market gardening sites, and point F4 is positioned downstream of Niamey with several human activities and after the market gardening sites and the irrigated areas of Saga and Liboré. Point F6 is located at the confluence of the Mékrou River with the Niger River, and allows for the evaluation of pesticide contamination from this river; and finally, point F7, located in Gaya, which is a Sahelo-Sudanese area and at the exit of the Niger River from Niger territory, to evaluate pesticide inputs from the Niger side.

\subsubsection{Materials and sampling method}

\section{Materials}

The sampling materials used consisted of a $\mathrm{pH}$ meter and a conductivity meter for in situ measurements of physical parameters and $1 \mathrm{~L}$ and $500 \mathrm{~mL}$ glass vials. Filtration was performed using a Nalgene filtration unit (for GL45 flask), a hand pump and GF/F disposable filters. The Oasis HLB cartridges were conditioned at the IMT Mines Alès with $5 \mathrm{~mL}$ of acetonitrile under vacuum, followed by $5 \mathrm{~mL}$ of methanol $(\mathrm{MeOH})$ and $5 \mathrm{~mL}$ of ultrapure water (Ibrahim et al., 2013b) and transported in a cooler to Niger.

For both (2) types of sampling, a membrane pump was used for filtration during the extractions work.

\section{Method}

The grab sampling and passive sampling campaigns were carried out during the winter season between August and September and the dry season between April and May. They concerned the six (6) sampling sites selected in order to better evaluate the contamination in the same hydrological context of the Niger River. At each site, in situ measurements were made to collect the $\mathrm{pH}$ and conductivity of the environment and the POCIS are deployed in triplicate (3 POCIS) for a period of 15 to 20 days. They are placed in a cage, attached to an empty canister that floats and immersed vertically in river water. Upon removal, the POCIS are rinsed with Milli Q water, wrapped in aluminum foil, then in a plastic bag and stored in a cooler before being transported to the laboratory for extraction. 
Water samples are collected manually in 1-liter glass bottles (grab sampling) previously rinsed with the water to be sampled, on the days of deployment and withdrawal of POCIS. They are also kept in a cooler during transport before the extraction phase.

\subsubsection{Extraction of water grab samples and POCIS}

The extraction phase of the water samples was carried out in Niger. The collected water was divided into two $500 \mathrm{~mL}$ flasks, and vacuum filtered using a Nalgene filtration unit with a $0,7 \mu \mathrm{m}$ pore size GF/F filter; in order to remove suspended matter. On each filter, $50 \mu \mathrm{L}$ of atrazine was added as an extraction yield tracer and the solid phase extraction on Oasis HLB® cartridges. These cartridges were stored in a refrigerator in Niamey before being transported to the laboratory at IMT Mines Alès. Before extraction, the Oasis HLB® cartridges were activated with $5 \mathrm{~mL}$ of acetonitrile under vacuum, followed by $5 \mathrm{~mL}$ of methanol (MeOH) and $5 \mathrm{~mL}$ of ultrapure water (Ibrahim et al. 2013b). The elution phase was performed at IMT Mines Alès after a $1 \mathrm{~h}$ vacuum drying. The analytes were then recovered by eluting the cartridges with $8 \mathrm{~mL}$ of acetonitrile at a flow rate of $1 \mathrm{~mL} / \mathrm{min}$ (Mhadhbiet al., 2019). For POCIS, a device was set up in Niamey to transfer the phases into an empty solid-phase tube (SPE) with two polyethylene frits with $20 \mu \mathrm{m}$ porosity at the base and top. A Visiprep solid phase extraction (SPE) collector from Supelco (Bellefonte, USA) was used.

The extracts from the extraction were concentrated under a gentle stream of nitrogen to obtain a final extract of $1.5 \mathrm{~mL}$, which were spiked with simazine d5 before being analyzed by HPLC-MS/MS (Ibrahim 2013).

\subsubsection{Liquid chromatography mass spectrometry analysis of polar pesticides (herbicides)}

The analysis of the extracts was performed at IMT Mines Alès by HPLC/MS/MS using an Alliance HPLC system (Waters Series 2695). This system is equipped with a quaternary pump, a degasser and a sample changer. Analytical separation was performed with a Kinetex C18 analytical column (100 mm × 4.6 I.D. × 260; Phenomenex) (Mhadhbi et al., 2019). Milli-Q water and acetonitrile, both including $0.05 \%$ formic acid, were used as the mobile phase, at a constant flow rate of $0.4 \mathrm{~mL} / \mathrm{min}$. The linear gradient started at $60 \%$ and reached $100 \%$ in $10 \mathrm{~min}$ to allow the passage of acetonitrile, followed by stabilization before returning to initial conditions for $2 \mathrm{~min}$. The system was coupled to a triple quadrupole mass spectrometer (Micromass Quattro micro MT, Waters) equipped with an electrospray ionization (ESI) source, used as a detection device and operated in positive ion mode. Argon was used as collision gas. Ion specific acquisition of each compound was performed in multiple reaction modes (MRN).

Thirty-two target compounds, consisting of twenty (25) pesticides (acetochlor, alachlor, atrazine, azoxystrobin, carbendazim, chlortoluron, dimethomorph, diuron, epoxiconazole, flazasulfuron, imidachloprid, isoproturon, linuron, metalaxyl, metholachlor, oxydiaxyl, prochloraz, propyzamide, prosulfocarb, pyrimethanil, simazine, tebuconazole, terbuthylazine, tetraconazole) and seven (7) degradation products (DCPMU, DCPU, DEA, DET, DIA, Simazine hydroxy and terbuthylazine hydroxy) were analyzed (Table 1).

The analytical results were recovered from two transitions, one for the quantification of the target substances and one for the confirmation. For POCIS, the sampling rates (Rs), were determined under laboratory conditions for each compound by dividing the slope of the linear regression curve by the average aqueous concentration of selected compounds over a 15-day period (Ibrahim et al. 2012, 2013). Some of the sample rates were not determined at ITM Mines Alès and were therefore retrieved from the literature (Ahrens et al. 2015; Desgranges 2015; Greenwood et al. 2007; Poulier et al. 2014, Branchet et al. 2018). 
Table 1

Limit of detection (LOD) and limit of quantification (LOQ) obtained by HPLC/MS and limit of quantification (LOQ) for water samples and LOQ calculated for POCIS under laboratory conditions.

\begin{tabular}{|c|c|c|c|c|c|c|c|}
\hline $\begin{array}{l}\text { Active } \\
\text { Substances }\end{array}$ & Chemical Family & $\begin{array}{l}\text { Analytical } \\
\text { LOD } \\
(\mu \mathrm{g} / \mathrm{L})\end{array}$ & $\begin{array}{l}\text { Analytical } \\
\mathrm{LOQ} \\
(\mu \mathrm{g} / \mathrm{L})\end{array}$ & $\begin{array}{l}\text { Water } \\
\text { LOD } \\
\text { (ng/L) }\end{array}$ & $\begin{array}{l}\text { Water } \\
\text { LOQ } \\
\text { (ng/L) }\end{array}$ & $\begin{array}{l}\text { Accumulation } \\
\text { Rate Rs } \\
\text { (L/day) }\end{array}$ & Reference \\
\hline \multicolumn{8}{|l|}{ Herbicides } \\
\hline Acetochlor & chloroacetamide & 1,3 & 4,3 & 3,9 & 13,0 & 0,223 & $\begin{array}{l}\text { Ibrahim et } \\
\text { al. 2013a }\end{array}$ \\
\hline Alachlor & chloroacetamide & 2,7 & 9,1 & 8,3 & 27,5 & 0,256 & $\begin{array}{l}\text { Ibrahim et } \\
\text { al. 2013a }\end{array}$ \\
\hline Atrazine & Triazine & 1,7 & 5,8 & 5,2 & 17,4 & 0,254 & $\begin{array}{l}\text { Ibrahim et } \\
\text { al. 2013a }\end{array}$ \\
\hline Chlortoluron & Urea & 1,7 & 5,6 & 5,1 & 17,0 & 0,252 & $\begin{array}{l}\text { Ibrahim et } \\
\text { al. 2013a }\end{array}$ \\
\hline DCPMU & Urea & 1,9 & 6,5 & 5,9 & 19,6 & 0,285 & $\begin{array}{l}\text { Ibrahim et } \\
\text { al. 2013a }\end{array}$ \\
\hline DCPU & Urea & 4,2 & 14,0 & 12,8 & 42,5 & 0,333 & $\begin{array}{l}\text { Ibrahim et } \\
\text { al. } 2013 \mathrm{~b}\end{array}$ \\
\hline DET & Triazine & 0,6 & 1,9 & 1,7 & 5,7 & 0,254 & $\begin{array}{l}\text { Ibrahim et } \\
\text { al. 2013b }\end{array}$ \\
\hline DIA & Triazine & 1,2 & 3,9 & 3,6 & 12,0 & 0,068 & $\begin{array}{l}\text { Ibrahim et } \\
\text { al. 2013a }\end{array}$ \\
\hline Diuron & Phenylurea & 1,7 & 5,8 & 5,3 & 17,5 & 0,257 & $\begin{array}{l}\text { Ibrahim et } \\
\text { al. 2013a }\end{array}$ \\
\hline Flazasulfuron & Sulfonylurea & 1,8 & 6,1 & 5,5 & 18,4 & Indisponible & \\
\hline Isoproturon & Urea & 3,4 & 11,3 & 10,3 & 34,3 & 0,237 & $\begin{array}{l}\text { Ibrahim et } \\
\text { al. 2013a }\end{array}$ \\
\hline Linuron & Urea & 2,7 & 9,1 & 8,2 & 27,5 & 0,141 & $\begin{array}{l}\text { Ibrahim et } \\
\text { al. 2013a }\end{array}$ \\
\hline Metolachlor & chloroacetanilide & 4,5 & 14,9 & 9,8 & 45,0 & 0,268 & $\begin{array}{l}\text { Ibrahim et } \\
\text { al. 2013b }\end{array}$ \\
\hline Oxadixyl & Phenylamide & 1,6 & 5,3 & 4,8 & 16,1 & 0,263 & $\begin{array}{l}\text { Ibrahim et } \\
\text { al. 2013a }\end{array}$ \\
\hline Propyzamide & Benzamide & 3,1 & 10,2 & 9,3 & 31,0 & 0,195 & $\begin{array}{l}\text { Ibrahim et } \\
\text { al. 2013a }\end{array}$ \\
\hline Prosulfocarbe & Thiocarbamate & 2,7 & 9,1 & 8,3 & 27,7 & 0,071 & $\begin{array}{l}\text { Ibrahim et } \\
\text { al. 2013a }\end{array}$ \\
\hline Simazin & Triazine & 1,5 & 5,1 & 4,5 & 15,5 & 0,218 & $\begin{array}{l}\text { Ibrahim et } \\
\text { al. 2013a }\end{array}$ \\
\hline $\begin{array}{l}\text { Simazine } \\
\text { hydroxy }\end{array}$ & Triazine & 2,6 & 8,8 & 8,0 & 26,7 & Indisponible & \\
\hline Terbutylazine & Triazine & 1,7 & 5,6 & 5,1 & 17,0 & 0,163 & $\begin{array}{l}\text { Ibrahim et } \\
\text { al. 2013a }\end{array}$ \\
\hline
\end{tabular}




\begin{tabular}{|c|c|c|c|c|c|c|c|}
\hline $\begin{array}{l}\text { Active } \\
\text { Substances }\end{array}$ & Chemical Family & $\begin{array}{l}\text { Analytical } \\
\text { LOD } \\
(\mu \mathrm{g} / \mathrm{L})\end{array}$ & $\begin{array}{l}\text { Analytical } \\
\mathrm{LOQ} \\
(\mu \mathrm{g} / \mathrm{L})\end{array}$ & $\begin{array}{l}\text { Water } \\
\text { LOD } \\
\text { (ng/L) }\end{array}$ & $\begin{array}{l}\text { Water } \\
\text { LOQ } \\
\text { (ng/L) }\end{array}$ & $\begin{array}{l}\text { Accumulation } \\
\text { Rate Rs } \\
\text { (L/day) }\end{array}$ & Reference \\
\hline $\begin{array}{l}\text { Terbutylazine } \\
\text { hydroxy }\end{array}$ & Triazine & 2,7 & 9,1 & 8,3 & 27,7 & Indisponible & \\
\hline \multicolumn{8}{|l|}{ Fungicides } \\
\hline Azoxystrobin & Strobilurin & 0,9 & 3,0 & 2,7 & 9,0 & 0,154 & $\begin{array}{l}\text { Ibrahim et } \\
\text { al. } 2013 a\end{array}$ \\
\hline Carbendazime & Bendimidazole & 7,2 & 24,0 & 21,8 & 72,8 & 0,304 & $\begin{array}{l}\text { Poulier et } \\
\text { al. } 2015\end{array}$ \\
\hline Dimethomorphe & Morpholine & 4,9 & 16,4 & 15,0 & 49,8 & 0,395 & $\begin{array}{l}\text { Poulier et } \\
\text { al. } 2016\end{array}$ \\
\hline Epoxiconazole & Triazole & 1,4 & 4,7 & 4,2 & 14,1 & 0,28 & $\begin{array}{l}\text { Ahrens et } \\
\text { al. } 2015\end{array}$ \\
\hline Metalaxyl & Phenylamide & 3,2 & 10,7 & 9,8 & 32,6 & 0,264 & $\begin{array}{l}\text { Ibrahim et } \\
\text { al. } 2013 a\end{array}$ \\
\hline Penconazole & Triazole & 2,0 & 6,6 & 6,0 & 19,9 & 0,279 & $\begin{array}{l}\text { Ibrahim et } \\
\text { al. } 2013 a\end{array}$ \\
\hline Prochloraz & Azole & 3,3 & 11,0 & 10,0 & 33,4 & 0,08 & $\begin{array}{l}\text { Desgranges } \\
2015\end{array}$ \\
\hline Pyrimethanil & Anilinopyrimidine & 0,6 & 2,0 & 1,8 & 6,1 & 0,231 & $\begin{array}{l}\text { Ibrahim et } \\
\text { al. } 2013 a\end{array}$ \\
\hline Tebuconazole & Triazole & 1,1 & 3,6 & 9,7 & 10,9 & 0,24 & $\begin{array}{l}\text { Greenwood } \\
\text { et al. } 2007\end{array}$ \\
\hline Tetraconazole & Triazole & 3,2 & 10,6 & 9,7 & 32,2 & Indisponible & \\
\hline \multicolumn{8}{|l|}{ Insecticides } \\
\hline Imidacloprid & Neonicitinoïd & 1,4 & 4,5 & 4,1 & 13,7 & 0,29 & $\begin{array}{l}\text { Poulier et } \\
\text { al. } 2015\end{array}$ \\
\hline
\end{tabular}

\subsubsection{Quality Assurance/Control}

The linearity, LOQs and LODs, precision and accuracy of the analytical methods were carefully analyzed. LODs were calculated as $3 \times \mathrm{Sy} / \mathrm{x} / \mathrm{b}$ and LOQs as $10 \times \mathrm{Sy} / \mathrm{x} / \mathrm{b}$, where Sy/x is the residual standard deviation and $\mathrm{b}$ is the slope of the matrix calibration curves. The LODs and LOQs obtained by HPLC/MS (analytical LODs and LOQs expressed in $\mu \mathrm{g} / \mathrm{L}$ ) are listed in Table 1. The LOD and LOQ of all selected pesticides were determined from the calibration lines for each analytical campaign in which R2 $>0.98$. For the POCIS, the analytical detection limit ranged from 0.10 to $2.20 \mu \mathrm{g} / \mathrm{L}$ and the limit of quantification from 0.40 to $7.50 \mu \mathrm{g} / \mathrm{L}$.

The average recovery in the synthetic water solution spiked with the 32 targeted compounds (acetochlor, alachlor, atrazine, azoxystrobin, carbendazim, chlortoluron, dimethomorph, diuron, epoxiconazole, flazasulfuron, imidachloprid, isoproturon, linuron, metalaxyl, metholachlor, oxadixyl, penconazole, prochloraz, propyramide, prosulfocarb, pyrimethamil, simazine, tebuconazole, terbuthylazine, tetraconazole, DCPMU, DCPU, DEA, DET, DIA, Simazine hydroxyl, terbuthylazine hydroxy) was $63 \%$, with the highest recovery for simazine (101\%) and the lowest for DPCU (8\%). Flazasulfuron, terbuthylazine hydroxy, and simazine hydroxy were not recovered. 
A certified reference material (WaR ${ }^{\mathrm{TM}}$ Pollution Nitrogen Pesticides, Lot No. P246-674) from ERA Waters Company (Golden, USA) was used to determine pesticide recoveries in water samples. This reference material is an aqueous solution composed of 24 pesticides including the 6 pesticides selected in our study (alachlor, atrazine, DEA, DIA, metolachlor and simazine). Pesticide concentrations in the reference material ranged from 3.37 to $16.80 \mu \mathrm{g} / \mathrm{L}$. The recoveries and coefficients of variation were $108 \pm 4 \%$ (atrazine), $78 \pm 4 \%$ (alachlor), $61 \pm 3 \%$ (DEA), $58 \pm 3 \%$ (DIA), $110 \pm$ $2 \%$ (metolachlor), and $79 \pm 2$ (simazine) after solid-phase extraction (Oasis HLB) and HPLC/MS/MS analysis $(n=9)$ of the reference material using the same analytical method.

The average recoveries with atrazine-d5 were $98 \pm 11 \%$ and $90 \pm 12 \%$ for spot and passive samples respectively $(n=33$ samples). The average coefficient of variation with the internal standard simazine-d5 was $17 \pm 6 \%$ for all HPLC/MS injections ( $n=120$ injections).

\subsubsection{Statistical analysis of data}

For all analyses, triplicate analytical measurements were performed and data were tabulated as mean \pm standard deviation. Statistical treatments of the data was performed using STATISTICA analysis software and statistical significance was set at $p<0.05$.

\section{Results And Discussion}

\subsection{Results of the survey on agricultural practices and phytosanitary products}

In Niger, there is no database on pesticide management, particularly export and consumption, and the porous nature of the borders facilitates the sale of fraudulent and toxic products. The results of the surveys carried out showed that $95 \%$ of the producers are illiterate men and $60 \%$ reported having received training in the use of pesticides. The area cultivated under irrigation in the surveyed zone represents about 390 ha and the area of market gardening sites is about 10 ha. The main crops inventoried in the market gardening site are tomatoes, lettuce, cabbage, peppers, carrots, zucchini, parsley, celery and lettuce, which are grown mainly during the dry season.

Pesticides are used in these crop areas by all producers, depending on the time of year and type of crop, to improve yields by controlling pests such as caterpillars, termites, grasshoppers, crickets, locusts, worms and weeds. Seventy percent $(70 \%)$ of the pesticides used are not approved by the Inter-State Committee for Drought Control in the Sahel (CILSS) and some are banned in Niger. Unfortunately, these products are sold in $1 / 4$ liter bottles in the markets of Liboré and Saga, near the selected site of F4. Sixty percent (60\%) of producers claim to have received guidance on the dangerousness of certain pesticides on human health, such as the case of daksh which stings the eyes and nose, and some products have reduced their effectiveness in recent years and are used 3 times with an interval of 3 days; thus doses twice (2) higher than those recommended on the labels, with the consequence of weakening the leaves, such as that of melon. Seventy-five percent $(75 \%)$ of the trained producers pointed out a lack of recycling of the training received, forty $(40 \%)$ of the respondents reported a total lack of training and only less than $10 \%$ expressed satisfaction. The results of the survey made it possible to draw up an inventory of pesticides on sale in the zone and showed that producers use several types of commercial products with $48 \%$ of active ingredients for insecticides, $45 \%$ for herbicides and $7 \%$ for fungicides. The producers do not have appropriate storage facilities for pesticides and in sites F4 et F6, empty packaging is also found discarded in the wild.

The survey revealed that the majority of producers, including those who have already been trained, are not aware of the doses to be applied, the frequency of treatment and the effects on health and the environment. They fail to follow 
procedures and some do not use personal protection équipementsduring treatment (Le Bars et al., 2015; Massalatchi et al., 2017). Several studies in African countries have shown that the use of inappropriate materials for pesticide dosing by mostly illiterate producers is a factor that can increase their exposure (Cissé et al., 2003; Traoré et al., 2006; Kanda et al., 2009; Doumbia and Kwadjo 2009; Ngom et al., 2013, Ahouangninou et al. 2011; Ogbeide et al., 2015; Son et al., 2017; Norbet et al., 2017; Lehmann et al., 2017 and 2018; Gouda et al. 2018; Le Bars et al., 2020).

Table 2 below provides a non-exhaustive list of active ingredients inventoried at somes sites F4 and F6 in the study area according to pesticide type, pest type and crop type. Of the thirty-two (32) compounds analyzed at ITM Mines Alès, 28\% are registered in Niger and are included in the list of pesticides registered by the Sahelian Pesticides Committee (CSP INSAH 2015; PPAAO, 2016). Of all active ingredients found in the study area, 15\% are analyzed at ITM Mines Alès by HPLC/MS/MS, corresponding to $27 \%$ of herbicides. These herbicides are used extensively in rice cultivation to control weeds and are applied in double cropping during the year (winter and off-season). Some active ingredients are registered in Niger, others are banned in Niger and the CSP, and some are analyzed at ITM Mines Alès. 
Table 2

Inventory of active substances used in agriculture along the Niger River in Niamey

$\begin{array}{llll}\text { Active substances Active ingredient family Target pests } & \text { Crop type }\end{array}$

\section{Herbicides}

\begin{tabular}{|c|c|c|c|}
\hline Acetochlor ${ }^{b, c}$ & Chloroacetanilide & $\begin{array}{l}\text { Mono and dicotyledonous } \\
\text { weeds }\end{array}$ & Cotton, corn, peanuts \\
\hline Atrazine ${ }^{b, c}$ & Chlorotriazine & Annual weeds & Cereal crops \\
\hline $\begin{array}{l}\text { Dichloride } \\
\text { Paraquat }^{\text {b }}\end{array}$ & Bypirydilium & $\begin{array}{l}\text { Mono and dicotyledonous } \\
\text { weeds }\end{array}$ & Vegetable and cereal crops \\
\hline Glyphosate $^{a}$ & Organophosphor & $\begin{array}{l}\text { Mono and dicotyledonous } \\
\text { weeds }\end{array}$ & Vegetable and fruit crops \\
\hline Propanil $^{\mathrm{a}}$ & Anilide & Annual and perennial weeds & Rice \\
\hline Butachlor & Chloroacetanilide & Annual and perennial weeds & Rice and vegetables \\
\hline Bensulfirion-methyl & Pyrimidinylsulfonylurea & Annual and perennial weeds & Rice \\
\hline $\begin{array}{l}\text { Haloxyfop-R } \\
\text { Methyl }^{\mathrm{a}}\end{array}$ & Organophosphate & Monocotyledonous weeds & All crops \\
\hline Pendimethalin & Dinitroaniline & Annual weeds & Vegetable crops \\
\hline Oxadiazon & Oxadiazolone & Annual and perennial weeds & Rice \\
\hline Propanil $^{\mathrm{a}}$ & Anilide & Annual and perennial weeds & Rice \\
\hline Propanil + 2.4-D & Phénoxyacetic acid & Annual and perennial weeds & Rice \\
\hline $\begin{array}{l}\text { Pyrazosulfuron- } \\
\text { éthyl }\end{array}$ & Pyrazole & Mono and dicot weeds & Rice \\
\hline
\end{tabular}

\section{Fungicides}

\begin{tabular}{llll}
$\begin{array}{l}\text { Carbenzadime } \\
\text { mancozeb }\end{array}$ & $\begin{array}{l}\text { Carbamate }+ \\
\text { Dithiocarbamate }\end{array}$ & $\begin{array}{l}\text { Anthracnose, alternaria, } \\
\text { mildew, powdery mildew }\end{array}$ & Rice, sugar cane \\
\hline Chlorothalonil $^{\text {a }}$ & Organochlorine & $\begin{array}{l}\text { Anthracnose, alternaria, } \\
\text { mildew }\end{array}$ & Vegetable crops \\
\hline
\end{tabular}

\section{Insecticides}

\begin{tabular}{|c|c|c|c|}
\hline Abamectin $^{a}$ & Avermectin & $\begin{array}{l}\text { Sucking pests, caterpillars, } \\
\text { leaf miners }\end{array}$ & Vegetable crops \\
\hline $\begin{array}{l}\text { Acetamiprid }^{\mathrm{a}}+ \\
\text { Indoxacarbe }^{\mathrm{a}}\end{array}$ & $\begin{array}{l}\text { Neonicotinoïd + } \\
\text { Oxidiazine }\end{array}$ & Sucking pests, caterpillars & $\begin{array}{l}\text { Vegetable and green bean } \\
\text { crops }\end{array}$ \\
\hline $\begin{array}{l}\text { Acetamiprid }^{\mathrm{a}}+ \\
\text { Lambda-cyhalothrin }^{-}\end{array}$ & $\begin{array}{l}\text { Neonicotinoid + } \\
\text { pyrethroid }\end{array}$ & Sucking bugs, caterpillars, & Vegetable crops \\
\hline Carbofuran ${ }^{\mathrm{b}}$ & Carbamate & $\begin{array}{l}\text { Nematodes, caterpillars, } \\
\text { sucking bites, termites }\end{array}$ & Vegetable crops \\
\hline Chlorpyrifos & Organophosphorus & $\begin{array}{l}\text { Sucking bites, termites, } \\
\text { aphids, white flies, caterpillars }\end{array}$ & $\begin{array}{l}\text { Vegetable and cereal crops, } \\
\text { cowpea, rice, maize, sorghum, }\end{array}$ \\
\hline
\end{tabular}




\begin{tabular}{|c|c|c|c|}
\hline Active substances & Active ingredient family & Target pests & Crop type \\
\hline Dichlorvos & Organophosphate & Broad spectrum of insects & All crops \\
\hline $\begin{array}{l}\text { Emamectin } \\
\text { benzoate }^{a}\end{array}$ & Avermectin & Caterpillar & Vegetable crops \\
\hline $\begin{array}{l}\text { Cyperméthrin }{ }^{\mathrm{a}}+ \\
\text { diméthoate }\end{array}$ & $\begin{array}{l}\text { Pyréthroid and } \\
\text { organophosphate }\end{array}$ & Sucking bugs & Vegetable crops \\
\hline Deltamethrin ${ }^{a}$ & Pyréthroid & $\begin{array}{l}\text { Caterpillar, aphids, flies, trips, } \\
\text { sucking bites }\end{array}$ & Vegetable crops and rice \\
\hline Fipronil $^{b}$ & Phenypyrazole & $\begin{array}{l}\text { Sucking bites, caterpillars, } \\
\text { beetles }\end{array}$ & Vegetable crops \\
\hline Imidacloprid ${ }^{a, c}$ & Néonicotinoid & $\begin{array}{l}\text { Sucking pests, bugs, } \\
\text { caterpillars, termites, beetles }\end{array}$ & Vegetable crops \\
\hline $\begin{array}{l}\text { Lambda-cyhalothrin } \\
+ \text { Dimethoate }^{\mathrm{a}}\end{array}$ & $\begin{array}{l}\text { Pyrethroid }+ \\
\text { organophosphate }\end{array}$ & $\begin{array}{l}\text { Sucking bugs, aphids, } \\
\text { caterpillars, grasshoppers, } \\
\text { beetles }\end{array}$ & Vegetable crops and rice \\
\hline
\end{tabular}

Additional Sources fo information (DPV 2003): Suplly center, Rice Cooperatives, POs and Authorized Distributors

a : pesticides approved by the Sahelian Pesticides Committee (CSP)

b: product banned in Niger and by the CSP

C: product analyzed at IMT Mines Alès

\subsection{Analysis of the results of grab and passive sampling (POCIS) 3.2.1 Frequency of detection and quantification of herbicides and fungicides in the Niger River}

For all the sampling campaigns, twelve pesticides, including ten (10) herbicides composed of acetochlor, alachlor, diuron and its metabolites (DCPMU and DCPU), atrazine and its metabolites (DEA and DIA) atrazin-desethyl-DEA and simazin and two fungicide compounds metalaxyl and tebuconazole were detected, representing $38 \%$ of the compounds analyzed and $32 \%$ were quantified (Figures 2 and 3 ). For the grab samples, DCPMU and the fungicide tebuconazole were never detected or quantified and the fungicide metalaxyl was detected but never quantified. DCPU was not detected and quantified in POCIS and the herbicide tebuconazole was only detected and quantified at low concentrations in POCIS. Alachlor was detected but not quantified in any of the samples.

The detection and quantification frequencies depend on the types of pesticides and the sampling periods. According to the results of the two sampling campaigns, the POCIS show the highest detection frequencies with $86 \%$ for acetochlor, $71 \%$ for DIA and $64 \%$ for diuron, atrazine and metalaxyl. The highest percentage of quantification frequencies (Figure 3 ) are for POCIS sampled during the rainy season campaign between June and September 2019 and the lowest percentages for both sampling types are between April and May.

During the rainy season, the pesticides with the highest quantification frequencies in the grab and passive samplings were diuron with $60 \%$, atrazine with $40 \%$ and acetochlor with over $20 \%$. No high concentrations were found for fungicides. 


\subsubsection{Contamination of the waters of the Niger River and the Mekrou River by herbicides and fungicides \\ 3.2.2.1 For grab sampling}

The highest concentrations, with quantification frequencies greater than $20 \%$, were found for the grab sampling. The main pesticides encountered were: diuron $(3281 \pm 222 \mathrm{ng} / \mathrm{L})$ and atrazine $(1476 \pm 65 \mathrm{ng} / \mathrm{L})$ with its degradation products, followed by acetochlor $(255 \pm 9.3 \mathrm{ng} / \mathrm{L}$ ). The two main pesticides (diuron and atrazine) were measured for the site $\mathrm{F} 6$ located at the confluence of the Mekrou River and the Niger River in samples collected during the month of August. The highest concentration of acetochlor was measured for the site F4 during September, at the exit of the city of Niamey. Pesticide concentrations in the water sampled at F6 decreased over three weeks (August 09-30) and ranged from $3281 \pm 222$ to $1057 \pm 100 \mathrm{ng} / \mathrm{L}$ for diuron and from $1476 \pm 65$ to $814 \pm 42 \mathrm{ng} / \mathrm{L}$ for atrazine. Atrazine metabolites showed stable concentrations and no variation during the three (3) weeks $(99 \pm 3.4 \mathrm{ng} / \mathrm{L}$ for DEA and 35.9 $\pm 3.2 \mathrm{ng} / \mathrm{L}$ for DIA). During the same rainy season campaign, the other sampling points, F1, F2, F3, F4 and F7 show low concentrations of diuron with a detection limit of $19.1 \mathrm{ng} / \mathrm{L}$ and $18.7 \mathrm{ng} / \mathrm{L}$ for atrazine. The other dry season spot sampling campaigns show very low concentrations for all the molecules analyzed. The only acetochlor concentration observed during the rainy season was not observed during the dry season campaign (between April/May). The presence of acetochlor at this site could be related to a one-time contamination.

\subsubsection{For passive sampling by POCIS}

The use of passive sampling (POCIS) is recommended in the European Commission's guidance document (EC Guidance Document No. 19) and in the Directive 2013/39/EU (EU 2013) for priority substances as a complementary method for monitoring surface water contamination. POCIS was used in this study to assess its effectiveness in environmental monitoring along the River Niger.

Determination of pesticide concentrations in POCIS

Contaminant accumulation by passive samplers generally follows first-order kinetics with an initial integration phase followed by curvilinear and equilibrium partitioning phases (Branchet et al. 2018, Mhadhbi et al. 2019). In the linear region of POCIS retention, the amount of a chemical accumulated in the sampler (M) is described by Eq. (1) :

$M=C w . R s . t(1)$

Where Rs is the sampling rate (L/day), $\mathrm{CW}$ is the concentration of the compound in water (ng/L) and $\mathrm{t}$ is the exposure time (days).

The time-weighted average concentration (TWA) in water is calculated with Eq. (2):

C water $=$ C pocis. Mpocis $/$ Rs $\bullet$ t (2)

With

$\mathrm{CW}$ : average concentration of pesticide in water $(\mu \mathrm{g} / \mathrm{L})$

C pocis : concentration in POCIS $(\mu \mathrm{g} / \mathrm{g})$

Mpocis : mass of the absorbing phase in the POCIS (g)

Rs : sampling rate (L/day) 
The sampling rates (Rs) are involved in the conversion of the quantities of pesticides accumulated in the POCIS into concentration by nanograms per liter. The average Rs of the compounds, used in this study is $0.215 \mathrm{~L} / \mathrm{day}$ and the lowest values are for DIA $(0.068 \mathrm{~L} /$ day $)$ and DEA $(0.133 \mathrm{~L} /$ day $)$ assuming that their concentrations may have been underestimated (Branchet et al. 2018).

The highest concentrations are highlighted in POCIS for site F6 located at the confluence of the Mékrou River and the Niger River and sampled during the month of August. The two main pesticides are diuron with an average concentration of $311 \mathrm{ng} / \mathrm{L}$ and $217 \mathrm{ng} / \mathrm{L}$ for atrazine. The POCIS for sites F1, F2, F4 and F7 of the two campaigns gave results below the detection limit and therefore not usable.

\subsubsection{Summary of results obtained}

According to Directive 2008/105/EC, the concentration of acetochlor found for site F4 (255 $\pm 9.3 \mathrm{ng} / \mathrm{L})$ is two point five (2.5) times higher than the value of the environmental limit, that of diuron for site F6 (3281 $\pm 222 \mathrm{ng} / \mathrm{L})$ is fifteen (15) times higher than the norms and that of atrazine $(1476 \pm 65 \mathrm{ng} / \mathrm{L})$ is two (2) times higher than the norm. In all CILSS countries, there is a lack of knowledge of the fate and behavior of pesticides in small streams in agricultural watersheds, particularly due to the great variability of the slope inputs and the complexity of the phenomena involved (Rabiet et al. 2008). The intensive use of pesticides along the Niger River and its tributaries is the anthropogenic factor behind the high contamination of diuron, atrazine and acetochlor.

The high concentrations of atrazine and diuron measured in the waters of the Boumba site (F6) merit special attention, given the large quantities of pesticides used in intensive cotton farming, which is vulnerable to insect and other pest attacks. The Mekrou River has its source $80 \%$ in Benin and cotton cultivation is practiced on high altitudes and some of the pesticides used can easily run off into the Niger River. These transfers of pollutants from the application site at the level of the Mékrou River to the Niger River via the W Park, a Unesco World Heritage Site located on the borders of Niger, Benin and Burkina Faso, constitute a threat and can generate significant disruptions to the ecosystems. In the Beninese and Burkinabe parts, studies have highlighted the impact of pesticide use by riparian populations on ecosystems (Soclo et al., 2003; Son et al., 2017).

Although there is no data on the intensive use of pesticides in crops in southern Burkina on the Mekrou River, the high concentrations of pesticides found in Benin and Niger in this study show a potential for exposure to environmental and health impacts in this area. The potential impacts of pesticide use can result in decreased soil fertility and release of pollutants; water pollution by nitrate, ammonium $\mathrm{NH}_{4}{ }^{+}$and heavy metals ( $\mathrm{Pb}, \mathrm{Zn}, \mathrm{Mn}$ ) and other toxic compounds as well as acute poisoning, poisoning, decreased fertility and even deaths (Lawani et al. 2017). Table 3 below shows the concentrations observed for sites F4 and F6 during the rainy season. 
Table 3

Herbicide and fungicide concentrations of sites F4 and F6 during the rainy season.

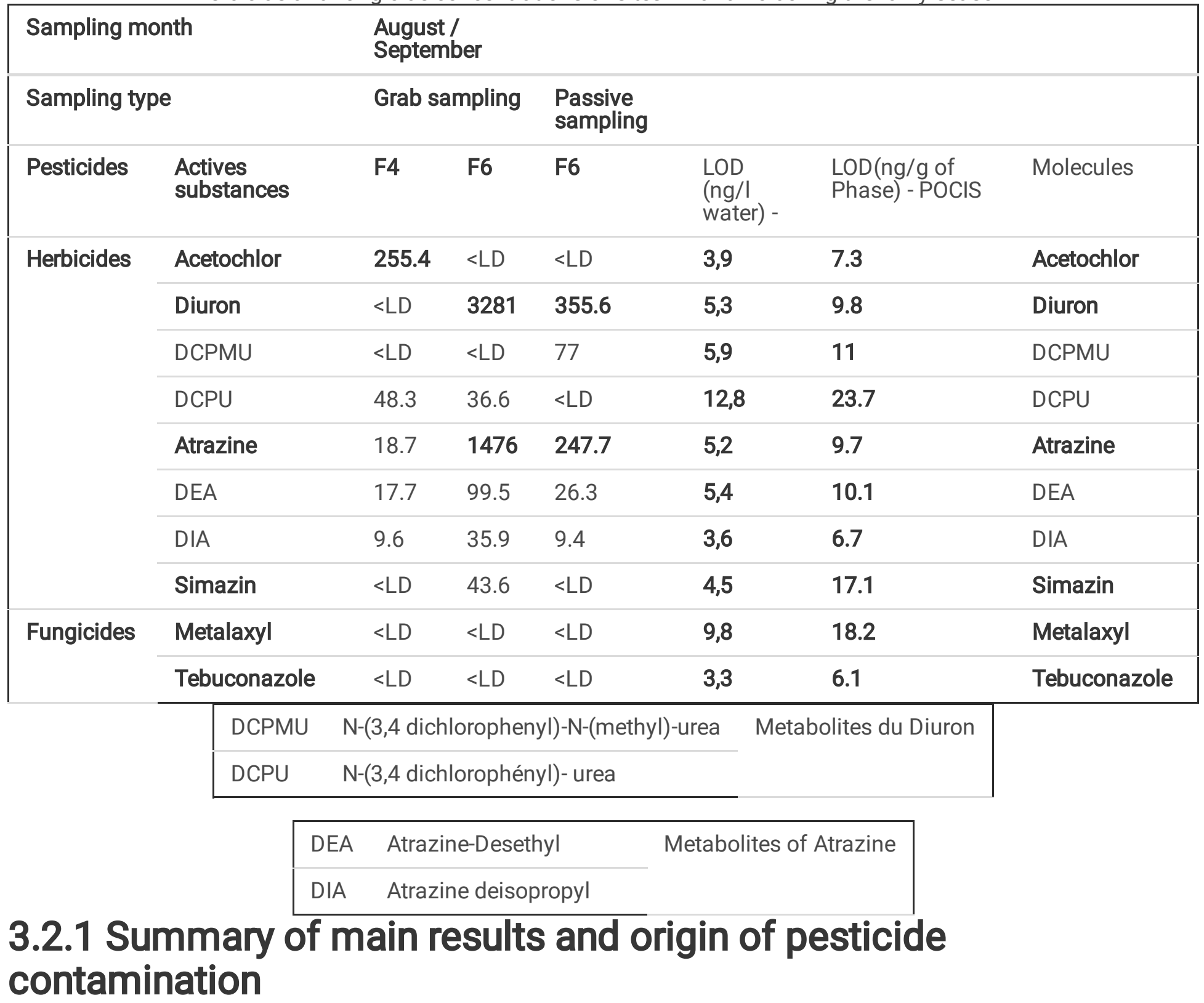

For the two sampling campaigns and the two types of sampling carried out per site, the highest concentrations are observed for diuron and atrazine followed by acetochlor. These concentrations are only observed for sites F4 and F6 sampled during the rainy season campaign. Diuron and atrazine are frequently quantified in streams (HerreroHernàandes et al., 2017; Mac Loughlin et al., 2017; Ryberg and Gilliom, 2005; Branchet et al. 2018).

The decrease in diuron and atrazine concentrations observed between the first and second grab sampling over a period of three (3) weeks may be related to the first effect of leaching of pesticides generated by heavy rains and concentrations had to be diluted with the increase in river flow for sites F4 on the Niger River and F6 on the Mekrou River (Palma et al. 2004). Sampling was conducted after the first rains in June and July upstream of the Niger River in Guinea, Mali, and Burkina, where it originates. During this same period, the Niger had recorded a few days of rainfall between July and August, after a long dry season from October to June. These first rains at the beginning of the rainy season may be the cause of the drainage of pollutants from the crops in the form of runoff, especially for the cotton crop in Benin on the Mekrou River and the vegetable crops in Niamey on the Niger River, thus explaining the strong 
variation of concentrations over a period of three (3) weeks. This process shows that there is an influence of rainfall and runoff on the concentration of pesticides in the waters of the Niger River and the Mekrou River (Figure 4 and 5).

The water sample during September, at the end of the rainy season, at point F4 showed very low concentrations of diuron and atrazine. This suggests that the pesticides would have been diluted in the August water stream and a seasonal variation in pesticide concentrations.

The presence of diuron and atrazine with highly variable concentrations at site F6, at the confluence of the Mekrou River and the Niger River, suggests a diffuse contamination of these molecules. The samples with the highest concentrations, during the first sampling, may be related to point contamination.

The graph Figure 4 shows the distribution of the average annual rainfall in Niger at stations near Niamey, the water level in the Niger River in 2019 and the distribution of the molecules diuron and atrazines analyzed.

The two (2) graphs show that the high concentrations of diuron and atrazine are located in the intermediate zone between the low water period and the arrival of the first rains in the Niger River and the Mekrou River. In all periods of the year when the water level and flow are very high, the concentrations of pesticides are diluted and become low.

Site F4 has a high concentration of acetochlor and is located downstream from the city of Niamey, where market gardening is practiced on the sites of Gamkalley and Saga with two (2) irrigated perimeters of Saga and Liboré for rice cultivation. Surveys conducted showed that farmers use different types of pesticides, depending on the crop, to control pests, diseases and weeds; and acetochlor is mainly used in vegetable crops. The origin of this contamination seems to be mainly related to urban agriculture and irrigated crops.

Pesticide contamination comes from the upstream part of the Mekrou River in the Beninese part of the border between the two countries. Benin is the leading cotton producing country in Africa and the Mekrou River is mostly affected by this production. This growth in cotton production is accompanied by the fraudulent use of pesticides of varying origin and quality to protect the crop (Agbohessi et al. 2011). The origin of this contamination therefore seems to be linked to intensive cotton farming.

In both types of agriculture, some of the applied pesticides can be adsorbed by soil particles and then transported to the Niger River or the Mekrou River by runoff (Chen et al., 2017; Fairbairn et al. 2016; Jorgenson et al. 2013; Mast el al. 2007; Smernik and Kookana 2015). The persistence of these pesticides in the environment is a function of their susceptibility to degradation and their adsorption to suspended solids. This allows for frequent encounters with pesticides that do not rapidly break down in the water column.

Among the pesticides found in high concentrations in the study area, acetochlor and atrazine are not registered by the Sahelian Pesticide Committee (SPC) and are banned in Niger because of their high toxicity and dangerousness. Their presence can be explained by their application on different crops.

In addition to the use of certain unregistered and banned pesticides, certain poor practices by farmers, particularly during the preparation, handling, spreading and storage of pesticides, can also contribute to environmental contamination.

The low concentrations recorded at site F2 show that the Sirba River, which originates in Burkina Faso, does not contribute pesticide pollution to the Niger River. The results of the analysis of the samples from sites F1 and F7 do not show any molecules with concentrations higher than the WHO and EU water quality standards. This shows that the water of the Niger River coming from Mali are not contaminated as well as its outlet to Nigeria. The absence of contamination upstream of the city of Niamey and its presence downstream and after the market gardening sites 
suggests that there is a link between the intensive use of unregistered pesticides and poor practices in the cultivation system.

\subsection{Ecological risk assessment}

The ecological risk assessment was based on the calculation of ecological risk quotient (ERQ), according to the OECD and European guidelines for diuron and atrazine. The RQ was calculated as a chronic toxicity test on three representative trophic levels which are: fish of species Oncorhynchus mykiss, algae of species Raphidocelis subcapitata and green algae and aquatic invertebrates of species Daphnia magna (Branchet et al. 2018). Daphnia magna species is one of the most commonly used species in ecotoxicological risk assessment. This organism was used in the aquatic ecotoxicology test sheet for the chronic ecotoxicity test (ISO, 10706; OECD, 1998). The Lowest Observed Effect Concentration (LOEC) for each selected pesticide was obtained from the University of Hertfordshire Pesticide Properties Database (https://sitem.herts.ac.uk/aeru/ppdb/en/index.htm). The LOEC corresponds to a 21-day chronic exposure for fish and aquatic invertebrates; and the median effective concentration (EC50) from a 72-h acute exposure was used for algae. The effects studied were growth inhibition for algae, immobilization for aquatic invertebrates and survival for fish (Branchet et al. 2018).

The estimated no effect concentration (PNEC) was calculated according to the formula. PNEC $=$ CMEO $/ 1000$. The value 1000 , corresponds to the safety factor applied to take into account the inherent uncertainty of the toxicity data obtained in the laboratory.

The risk quotient value RQ was calculated using the formula RQ = MEC / PNEC with MEC corresponding to the measured environmental concentration of the grab samples $(\mu \mathrm{g} / \mathrm{l})$. The highest concentration in each sample was considered.

The herbicides diuron and atrazine are the two main pesticides identified during the contamination survey. The calculated PNEC values for algae, aquatic invertebrates and fish are shown in Table 4 below.

The ecological risk assessment is presented in Table 4, taking into account the concentrations measured at all sampling sites on the Niger River and the Mekrou River. The measured environmental concentrations (MEC) used are the maximum values in each campaign, representing the worst case.

Table 4: Ecological risk quotient of sampling sites based on atrazine and diuron on three trophic levels

\begin{tabular}{|c|c|c|c|c|c|c|c|c|c|c|c|c|}
\hline \multirow{3}{*}{ Sites } & \multicolumn{4}{|l|}{ Algae } & \multicolumn{4}{|c|}{ Daphnia } & \multicolumn{4}{|l|}{ Fish } \\
\hline & \multicolumn{2}{|c|}{ August/september } & \multicolumn{2}{|c|}{ April/May } & \multicolumn{2}{|c|}{ August/september } & \multicolumn{2}{|c|}{ April/May } & \multicolumn{2}{|c|}{ August/september } & \multicolumn{2}{|c|}{ April/May } \\
\hline & Atrazine & Diuron & Atrazine & Diuron & Atrazine & Diuron & Atrazine & Diuron & Atrazine & Diuron & Atrazine & Diuron \\
\hline F1 & 0,13 & 7,07 & * & $*$ & 0,03 & 0,20 & $*$ & $*$ & 0,00 & 0,05 & $*$ & $*$ \\
\hline F2 & $*$ & $*$ & 0 & 0 & $*$ & $*$ & 0 & 0 & $*$ & $*$ & 0 & 0 \\
\hline F4 & 0,31 & 2,15 & 0 & 0 & 0,07 & 0,06 & 0 & 0 & 0,01 & 0,01 & 0 & 0 \\
\hline F6 & 25,01 & 1215,30 & $*$ & $*$ & 5,90 & 34,18 & $*$ & $*$ & 0,74 & 8,00 & $*$ & $*$ \\
\hline F7 & * & $*$ & 0 & 0 & $*$ & $*$ & 0 & 0 & $*$ & * & 0 & 0 \\
\hline
\end{tabular}

$\mathrm{QR}>1$ (high risk)

\section{$\mathrm{QR}$ entre 0.5 et 1 (medium risk)}

$\mathrm{QR}<0.5$ (low risk) 


\begin{tabular}{|c|}
\hline Diuron and Atrazine \\
\hline NB: Fish - Chronic 21 day NOEC ( $\mu \mathrm{g} \mathbb{I}^{1}$ ) - moderate Interpretation: \\
\hline NB: Aquatic invertebrates - Chronic 21 day NOEC ( $\left.\mu \mathrm{g} \mathbb{I}^{1}\right)$ - Interpretation moderate \\
\hline
\end{tabular}

According to the result, it can be seen that the ecological risks are only observed for sites F1, F4 and F6 for samples taken during the rainy season. Sites F1 and F4 present low algae risks for for Diuron, which has low concentrations compared to point F6.

Point F6 has high ecological risks for all three trophic levels during the rainy season, especially in August. Risks are very high for all three model species for diuron with an RQ as high as 1,215 for algae. Preira et al., 2015 denotes that diuron has an anti-androgenic effect in Nile tilapia that impairs its reproductive function; and those of Coquillé et al., 2015 show significant effects in the microalgae Tetraselmis suecica, notably on a $125 \%( \pm 2.3 \%)$ increase in doubling time and $25 \%( \pm 1.8 \%)$ increase in fluorescence relative to the presence of reactive oxygen species (ROS, by flow cytometry) and a $25 \%( \pm 1.8 \%)$ decrease in photosynthetic yield and $38 \%( \pm 1.9 \%)$ decrease in relative lipid content.

For atrazine, the risk is very high for algae and aquatic invertebrates and medium to low for fish. The work of Maries et al, 2000, shows that the responses of algae vary considerably, depending on the concentrations used, the duration and the species of algae tested and those of Torres and O'Flaherty 1976 highlights a decrease in chlorophyll content (41 to $67 \%$ ), after 7 days of exposure to $1 \mathrm{~g} / \mathrm{L}$ of atrazine in the green algae Chloralla vulgaris and Stigeoclonium and in the blue-green algae Oscillatoria lutea. WHO 1990, indicates that its bioaccumulation capacity in fish remains low.

The presence of diuron and atrazine, particularly at F4 and F6, constitutes a major ecological risk for the aquatic environment. No ecological risk was identified during the dry season and only diuron presents high risks for the three trophic levels.

\section{Conclusion}

The present study confirms the pesticide contamination of the waters of the Niger River and the Mekrou River by diuron, atrazine and acetochlor. The high pesticide concentrations in the study area are highlighted during the rainy season mainly at sampling site F6, at the confluence between the Niger River and the Mekrou River and at site F4 located along the Niger River, downstream of the market gardening sites and irrigated perimeters, near the city of Niamey. These sites are the most exposed to pesticide contamination in the Niger River area, but do not represent the integrity of their environment. The origin of this contamination seems to be linked to the increased use of pesticides in urban agriculture on the one hand and in intensive cotton farming in Benin on the other. The pesticide concentrations found could be influenced by the variation in rainfall, the increase in river flow and the availability of unregistered pesticides in Niger. They are higher during the first rains at the beginning of the rainy season and dilute with the increase in flow. Sampling with POCIS provided results similar to those of grab sampling and is therefore an appropriate method for environmental monitoring of pesticide contaminants in space and time along the Niger and Mekrou rivers, due to the lack of specialized laboratories for the analysis of organic pollutants, adequate sampling equipment, and the remoteness of some sites. The concentrations of diuron at more than sixteen (16) times the Environmental Quality Standard, atrazine and acetochlor at more than 2.5 times the standard constitutes a worrying situation on the quality of the waters of the Niger River and the Mekrou River. The ecological risk assessment highlighted a high risk for algae (Raphidocelis subcapitata,) aquatic invertebrates (Daphnia) and fish (Oncorhynchus mykiss) for diuron. That of atrazine is also very high for algae and aquatic invertebrates and medium to low for fish. 
Given the results of this initial work on pesticide contamination and the high ecological risks for point F6, it is necessary

to consider additional sampling along the Mekrou River in the direction of Benin and to set up environmental monitoring of the waters of the Niger River for a good understanding of the variation of contaminants over time and space.

\section{Declarations}

\section{Acknowledgements:}

- Sylvie SPINELI, Murielle AVEZAK and Marine BERTRAND for the chemical analyses and Analytical LOD and LOQ calculation

- Moussa KONATE for the determination of sampling points and advise

\section{Availability of data and materials}

All data generated or analysed during this study are included in this published article. They are openly available.

Declarations: Not applicable

\section{Funding information}

This study was financed by the Institut Mines Télécom Alès.

\section{Consent for Publication}

I Mahamadou, responsible of the the famers, give my consent for publishing our information for the agricultural practices and pesticides used during the survey worked done by Oumar El Farouk. I have discussed in details with him and give my approval for publishing all the result of the survey done.

My name will not be published on his article.

Ethical Approval: Not applicable

Consent to Participate: Not applicable

Competing Interests: Not applicable

\section{Authors Contributions}

The authors confirm contribution to the paper "Occurrences of polar pesticide contamination in Niger River valley and its tributary the Mekrou River, using POCIS passive samplers and survey of agricultural practices (Niger Republic)".

Oumar El Farouk MAMAN ILLATOU contributed to sampling, sampe preparation, survey of agricultural practices and pesticide use, analysis and results interpretation and writing the final manuscript.

Catherine GONZALES contributed to the program of sampling and sample preparation, analysis and interpretation of results and manuscript preparation.

Marc VINCHES contribute to the preparation of sampling, interpretation of results and manuscript preparation.

\section{References}


1. Adeyemi D, Anyakora C, Ukpo G, Adedayo A, Darko G (2011) Evaluation of the levels of organochlorine pesticideresidues in water samples of Lagos Lagoon using solid phase extraction method. Journal of Environmental Chemistry Ecotoxicology 3(6):160-166. http://www.academicjournals.org/jece June 2011 Available online ISSN-2141-226X @2011 Academic Journals

2. Agbohessi TP, Imorou Toko I, Yabi AJ, Dassoundo CFJ, Kestemont P (2011) Caractérisation des pesticides chimiques utilisés en production cotonnière et impacts sur les indicateurs économiques dans la commune de Banikoara au nord du Bénin. International Journal of Biological Chemical Sciences 5(5):1828-1841

3. Agbohessi TP, Toko II, Kestemont P (2012) Etat des lieux de la contamination des écosystèmes aquatiques par les pesticides organochlorés dans le Bassin cotonnier béninois. Cah Agric, vol. 21, n¹, 2012. https://doi.org/10.1684/agr.2012.0535

4. Agbohessi PT, Toko II, Ouédraogo A, Jauniaux T, Mandiki S, Kestemont P (2015) Assessment of the health status of wild fish inhabiting a cotton basin heavily impacted by pesticides in Benin (West Africa). Science of the Total Environment 2015, 506, 567-584

5. Agboyi LK, Ketoh GK, Martin T, Glitho T, Tamò M (2016) Résistance aux pesticides chez les populations de Plutella xylostella (Lepidoptera: Plutellidae) du Togo et du Bénin. Int J Trop Insect Sci 36, 204-210 (2016). https://doi.org/10.1017/S1742758416000138

6. Ahmadou Y, Kouebou C, Malaa D, Bourou S, Olina JP, Mbiandoun M (2016) Les engrais et les pesticides dans la riziculture périurbaine de la ville de Garoua, au Nord-Cameroun: cas de Nassarao et Boklé. International Journal of Innovation and Applied Studies. ISSN 2028-9324 Vol. 18 No. 1 Oct. 2016, pp. 26-35

7. Ahouangninou C, Martin T, Edorh P, Bio-Bangana S, Samuel O, St-Laurent L, Dion S, Fayomi D (2012) Characterization of Health and Environmental Risks of Pesticide Use in Market-Gardening in the Rural City of ToriBossito in Benin, West Africa. Journal of Environmental Protection, 2012, 3, 241-248 doi:10.4236/jep.2012.33030 Published Online March 2012 http://www.SciRP.org/journal/jep

8. Ahouangninou C, Fayomi BE, Martin T (2011) Évaluation des risques sanitaires et environnementaux des pratiques phytosanitaires des producteurs maraîchers dans la commune rurale de Tori-Bossito (Sud-Bénin). Cahiers Agricultures 20(3): 216-222. DOI: 10.1684/ agr.2011.0485

9. Ahrens L, Daneshvar AE, Lau A, Kreuger J (2015) Characterization of five passive sampling devices for monitoring of pesticides in water. Journal of Chromatography A, 1409(2015) 1-11

10. Andres L, Lebailly P (2011) Peri-urban Agriculture: The Case of Market Gardening in Niamey, Niger. African Review of Economics Finance 3:69-85

11. Baron C, Bonnassieux A, Maiga IM, Nguyen G (2010) Gouvernance hybride et viabilité des grands périmètres irrigués au Niger. Mondes en Développement 2010/3 (n¹51), PAGES 51 à 66

12. Berthe DS, Cobb JM, Mullins DE (2007) Pesticide residues in soil and water from four cotton growing areas of Mali, West Africa. J Agric Food Environ Sci 1:1-12

13. Branchet P, Cadot E, Fenet H, Sebag D, Ngatcha BN, Borrell-Estupina V, Ngoupayou JRN, Kengne I, Braun J-J, Gonzalez C (2018) Polar pesticide contamination of an urban and peri-urban tropical watershed affected by agricultural activities (Yaoundé, center region, Cameroon). Environ Sci Pollut Res 25:17690-17715. https://doi. org/10.1007/s11356-018-1798-4

14. Cissé I, Tandia AA, Fall ST, Diop EHS (2003) Usage incontrôlé des pesticides en agriculture périurbaine: cas zone des Niayes au Sénégal. Cah Etud Rec Francoph Agric 12:181-186

15. Chen L, Feng Q, He Q, Huang Y, Zhang Y, Jiang G, Zhao W, Gao B, Lin K, Xu Z (2017) Sources, atmospheric transport and deposition mechanism of organochlorine pesticides in soils of the Tibetan Plateau. Sci Total Environ 577:405412. https://doi.org/10.1016/j. scitotenv.2016.10.227

Page 20/27 
16. Coulibaly L, Coulibaly S, Kamagaté B, Sékongo N, Savané I, Gourène G (2012) Distribution des pesticides d’origine agricole et évaluation de la vulnérabilité des ressources en eaux dans un bassin versant transfrontalier: Cas du Comoé, Côte d'Ivoire. Eur J Sci Res 76(4):601-613

17. CSP INSAH (2015) Liste globale des pesticides autorisés. Version de Mai

18. Desgranges N (2015) Développement d'échantillonneurs passifs de type POCIS pour l'évaluation de la contamination en pesticides des eaux de bassins versants languedociens. Thèse de doctorat, Université de Bordeaux, Bordeaux

19. Di Carro M, Bono L, Magi E (2014) A simple recirculatingflow system for the cali-bration of polar organic chemical integrative samplers (POCIS): effect offlow rate ondifferent water pollutants. Talanta 120:30-33

20. Direction Protection des Végétaux (DPV) (2003) Forum sur la problématique de la protection des végétaux au Niger, Niamey 8 au 11 décembre 2003

21. Donald CE, Scott RP, Blaustein KL, Halbleib ML, Sarr M, Jepson PC, Anderson KA (2016) Silicone wristbands detect individuals' pesticide exposures in West Africa. R Soc open sci 3:160433. http://dx.doi.org/10.1098/rsos.160433

22. Doumbia M, Kwadjo KE (2009) Pratiques d'utilisation et de gestion des pesticides par les maraîchers en Côte d'Ivoire: cas de la ville d'Abidjan et deux de ses banlieues (Dabou et Anyama). Journal of Applied Biosciences 18:992-1002. ISSN 1997-5902

23. Ehrnrooth A, Dambo L, Jaubert R (2011) Projets et programme de développement de l'irrigation au Niger (1960 2010): Elément pour un bilan. Centre d'Etudes et d'Information sur la Petite Irrigation

24. Elisabeth Y, Pazou A, Laleye P, Boko M, Van Gestel CAM, Ahissou H, Akpona S, Van Hattum B, Swart K, Van Straalen NM (2006) Contamination of Fish by Organochlorine Pesticide Residues in the Ouémé River Catchment in the Republic of Bénin. Environ Int 32:594-599

25. Gouda A-I, Imorou TI, Salami S-D, Richert M, Scippo M-L, Kestemont P, Schiffers B (2018) Pratiques phytosanitaires et niveau d'exposition aux pesticides des producteurs de coton du nord du Bénin. Cah Agric 27:65002

26. Gnankiré O, Mouton L, Savadogo A, Martin T, Sanon A, Dabire RK, Vavre F, Fleury F (2013) Botype status and resistance to neonicotinoids and carbosulfan in Bemisia tabaci (Hemiptera: Aleyrodidae) in Burkina Faso, West Africa. International Journal of pest Management. Volume 59-102, 2013.

https://doi.org/10.1080/09670874.2013.771806

27. Greenwood R, Mills GA, Vrana B, Allan IJ, Aguilar-Martinez R, Morrison G (2007) Monitoring of priority pollutants in water using Chemcatcher passive sampling devices. In: Greenwood R, Mills G, Vrana B (eds) Comprehensive analytical chemistry 48: passive sampling techniques in environmental monitoring. Elsevier, Amsterdam, p 199

28. Guengant JP, Banoin M (2003) Dynamique des populations, disponibilités des terres et adaptation des régimes fonciers: le cas du Niger. FAO et Comité International de Coopération dans les Recherches Nationales en Démographie. 144 pages

29. Gushit JS, Ekanem EO, Adamu HM (2013) Utilization pattern and risk assessment of herbicides usage by farmers, marketers and agricultural extension workers (AEWs) in Plateau state Nigeria. Journal of Agricultural Science Research

30. Herrero-Hernández E, Rodríguez-Cruz MS, Pose-Juan E, Sánchez-González S, Andrades MS, Sánchez-Martín MJ (2017) Seasonal distribution of herbicide and insecticide residues in the water resources of the vineyard region of La Rioja (Spain). Sci Total Environ 609:161-171. https://doi.org/10.1016/j.scitotenv.2017.07

31. Ibrahim I, Togola A, Gonzalez C (2013a) Polar organic chemical integrative sampler (POCIS) uptake rates for 17 polar pesticides and degradation products: laboratory calibration. Environ Sci Pollut Res 20:3679-3687.

https://doi.org/10.1007/s11356-012-1284-3

Page $21 / 27$ 
32. Ibrahim I, Togola A, Gonzalez C (2013b) In-situ calibration of POCIS for the sampling of polar pesticides and metabolites in surface water. Talanta 116:495-500. https://doi.org/10.1016/j.talanta.2013.07.028

33. Illyassou KM, Rabani A, Ibrahim A, Hassane A, Alassane A (2015) Evaluation des risques écotoxicologiques des pratiques agrochimiques dans la vallée du Niger: régions de Tillabéry et Niamey. Annales de l’Université Abdou Moumouni. 1: 108-122

34. Illyassou KM, Adamou R, Schiffers B (2018) First diet survey in Niger River valley and acute risk assessment for consumers exposed to pesticide residues in vegetables. Tunisian Journal of Plant Protection 13(2):243-262

35. Illyassou KM, Adamou R, Schiffers B (2017) Risk assessment for small farmers exposed to plant protection products in the Niger River Valley. Comm. Appl. Biol. Sci, Ghent University, 81/n, 2017

36. ISO 10706 (2000) Water quality - Determination of long-term toxicity of substances to Daphnia magna Straus (Cladocera, Crustacea). ISO Standards

37. Jorgenson B, Fleishman E, Macneale KH, Schlenk D, Scholz NL, Spromberg JA, Werner I, Weston DP, Xiao Q, Young TM, Zhang M (2013) Predicted transport of pyrethroid insecticides from an urban landscape to surface water. Environ Toxicol Chem 32:2469-2477. https://doi.org/10.1002/etc.2352

38. Kanda M, Djaneye-Boundjou G, Wala K, Gnandi K, Batawila K, Sanni A, Akpagana K (2013) Application des pesticides en agriculturemaraîchère au Togo. VertigO - La revue électronique en sciences de l'environnement 13(1) 4-8. Disponible sur https://doi.org/10.4000/vertigo.13456

39. Kanda M, Wala K, Batawila K, Djaneye-Boundjou G, Ahanchedé A, Akpagana K (2009) Le maraîchage périurbain à Lomé: pratiques culturales, risques sanitaires et dynamiques spatiales. Cah Agric, vol. 18, n4, juillet-août 2009

40. Lawani RAN, Kelome NC, Agassounon DTM, Hounk JB, Adjagodo A (2017) Effets des pratiques agricoles sur la pollution des eaux de surface en république du Bénin. Larhyss Journal ISSN 1112-3680, n³0, Juin 2017, pp. 173190

41. Le Barbe L, Ale G, Millet B, Texier H, Borel Y (1993) Monographie des ressources en eaux superficielles de la République du Bénin. Paris, ORSTOM, 540 pages

42. Le Bars M, Sidibe F, Mandart E, Fabre J, Le Grusse P, Diakite CH (2020) Évaluation des risques liés à l'utilisation de pesticides en culture cotonnière au Mali. Cah. Agric. 2020, 29, 4 https://doi.org/10.1051/cagri/2020005

43. Lehmann E, Turrero N, Kolia M, Konaté Y, Alencastro LF (2017) Dietary risk assessment of pesticides from vegetables and drinking water in gardening areas in Burkina Faso. Science of The Total nvironment Volumes 601602:1 Decembre 2017, Pages 1208-1216

44. Lehmann E, Oltramare C, Dibié J-JN, Konaté Y, Alencastroa LF (2018) Assessment of human exposure to pesticides by hair analysis: The case of vegetable-producing areas in Burkina Faso. Environment International. Volume 111, February 2018, Pages 317-331

45. Leo JD-H (1992) Changes in livelihood strategies in northern Benin and their environment effects, 133. The Courier EC-ACP, pp 88-90

46. Mac Loughlin TM, Peluso L, Marino DJG (2017) Pesticide impact study in the peri-urban horticultural area of Gran La Plata, Argentina. Sci Total Environ 598:572-580. https://doi.org/10.1016/j.scitotenv. 2017.04.116

47. Mhadhbi T, Pringault O, Nouri H, Spinelli S, Beyrem H, Gonzalez C (2019) Evaluating polar pesticide pollution with a combined approach: a survey of agricultural practices and POCIS passive samplers in a Tunisian lagoon watershed. Environmental Science and Pollution Research (2019) 26:342-361 https://doi.org/10.1007/s11356018-3552-3

48. Mamane A, Tessier J-F, Bouvier G, Salamon R, Lebailly P, Raherison C, Baldi I (2016) Increase in the Risk of Respiratory Disorders in Adults and CHILDREN Related to Crop-Growing in Niger. Journal of Environmental Public Health Volume 2016 Article ID 9848520:8 pages. http://dx.doi.org/10.1155/2016/9848520 
49. Mamane A, Baldi I, Tessier J-F, Raherison C, Bouvier G (2014) Occupational exposure to pesticides and respiratory health. European Respiration Review 24:306-319. DOI:10.1183/16000617.00006014

50. Mamane A (2015) Effets sanitaires aigus de l'exposition aux pesticides en milieu rural. Thèse de Doctorat, Université de Bordeaux, France, $235 \mathrm{p}$

51. Mamadou A, Mazih A, Inezdane A (2005) L'impact des pesticides utilisés en lutte contre le criquet pèlerin (schistocerca gregaria Forskål, 1775) (orthoptera, acrididae) sur deux espèces de pimelia (coleoptera, tenebrionidae) au Niger. La revue électronique en sciences de l'environnement. Volume 6, numéro 3 / 2005. https://doi.org/10.4000/vertigo.3665

52. Mamadou A, Doumma A, Mazih A, Coulibaly BM (2008) Exposition aux organophosphorés en milieu rural nigérien: étude de l'activité enzymatique érythrocytaire des cholinestérases comme indicateur biologique. (Vertig0). La revue électronique en sciences de l'environnement, 8(3), 0-0

53. Marie ED, Geofrey IS, Philippe ER (2000) Toxicity of pesticides to aquatic microorganisms: a review. Environ Toxicol Chem 20(1):84-98, 2001 Printed in the USA. 0730-7268/01 \$9.001.00

54. Mast MA, Foreman WT, Skaates SV (2007) Current-use pesticides and organochlorine compounds in precipitation and lake sediment from two high-elevation national parks in the Western United States. Arch Environ Contam Toxicol 52:294-305. https://doi.org/10.1007/ s00244-006-0096-1

55. Multigner L, Kadhel P, Huc-Terki F, Thome J, Janky E, Auger J (2006) Exposure to chlordecone and male fertility in Guadeloupe (French West Indies). Epidemiology 17:S372

56. Ngom S, Manga A, Diop M, Thiam MB, Rousseau J, Cissé I, Traoré S (2013) Etude de l'évolution des résidus de pesticides dans les produits horticoles de grande consommation au Sénégal. Rev Ivoir Sci Technol 22:31-34

57. Norbert NT, Daniel Brice KN, Eric DN (2017) Évaluation des facteurs de risques environnementaux liés à la mauvaise utilisation des pesticides par les maraîchers au Cameroun: le cas de Balessing à l'Ouest Cameroun. Afrique SCIENCE 13(1) (2017) 91 - 100. ISSN 1813-548X

58. Okoumassoun L-E, Brochu C, DeBlois C, Akponan S, Marion M, Averill-Bates D, Denizeau F (2002) Vitellogenin in tilapia male fishes exposed to organochlorine pesticides in Ouémé River in Republic of Benin. Sci Total Environ 299:163-172

59. OECD (1998) OECD guideline for testing of Chemicals - Daphnia magna. Reproduction test. Experimenatl guideline

60. Ogbeide O, Tongo I, Ezemonye L (2015) Risk assessment of agricultural pesticides in water, sediment, and fish from Owan River, Edo State, Nigeria. Environ Monit Assess 187, 654 (2015). https://doi.org/10.1007/s10661-015-4840-8

61. Ojo J (2016) Pesticides use and health in Nigeria. Ife Journal of Science. Vol 18 No. 4(2016)

62. Palma G, Sánchez A, Olave Y, Encina F, Palma R, Barra R (2004) Pesticide levels in surface waters in an agricultural-forestry basin in Southern Chile. Chemosphere 57:763-770. https://doi.org/10. 1016/j.chemosphere.2004.08.047

63. Poulier G, Lissalde S, Charriau A, Buzier R, Delmas F, Gery K, Moreira A, Guibaud G, Mazzella N (2014) Can PoCIS be used in water framework directive (2000/60/EC) monitoring networks? A study focusing on pesticides in a French agricultural watershed. Sci Total Environ 497-498:282-292. https://doi.org/10.1016/j.scitotenv. 2014.08.001

64. Programme de productivité agricole en Afrique de l'Ouest (PPAAO) (2016) Plan de Gestion des Pestes (PGP), Niger. Conseil Ouest Africain et du Centre pour le Recherche et le Développement. CORAF / WECARD), Rapport

65. Rabiet M, Margoum C, Gouy V, Carluer N, Coquery M (2008) Transfert despesticides et mé taux dans un petit bassin versant viticole. $E^{\prime}$ tude pré liminaire del'influence des conditions hydrologiques sur le transport de ces contaminants. In: Ingé nieries Special issue "Azote, phosphore et pesticides Straté gies etperspectives de ré duction des flux", pp. 65-75

Page 23/27 
66. Ryberg KR, Gilliom RJ (2015) Trends in pesticide concentrations and use for major rivers of the United States. Sci Total Environ 538:431-444. https://doi.org/10.1016/j.scitotenv.2015.06.095

67. SOGREAH/BRGM (1981) Étude du plan de développement de l'utilisation des ressources en eau du Niger. éditions BRGM, Niamey

68. Soclo H (2003) Etude de l'impact de l'utilisation des engrais chimiques et pesticides par les populations. In: riveraines sur les écosystèmes (eau de surface, substrat des réserves de faune) dans les complexes des aires protégées de la Pendjari et du W. Rapport d'étude. CENAGREF, Cotonou

69. Smernik RJ, Kookana RS (2015) The effects of organic matter-mineral interactions and organic matter chemistry on diuron sorption across a diverse range of soils. Chemosphere 119:99-104. https://doi.org/

10.1016/j.chemosphere.2014.05.066

70. Sougnabe SP, Yandia A, Acheleke J, Brevault T, Vaissayre M, Ngartoubam LT (2010) Pratiques phytosanitaires paysannes dans les savanes d'Afrique centrale. Actes du colloque « Savanes africaines en développement: innover pour durer », 20-23 avril 2009, Garoua, Cameroun. Prasac, N'Djaména, Tchad; Cirad, Montpellier, France, cédérom

71. Son D, Somda I, Legreve A, Schiffers B (2017) Pratiques phytosanitaires des producteurs de tomate du Burkina Faso et risques pour la santé et l'environnement. Cash. Agric. 2017, 26, 25005. DOI: 10.1051/cagri/2017010

72. Tarnagda B, Tankoano A, Tapsoba F, Sourabié PB, Abdoullahi HO, Djbrine AO, Drabo KM, Traoré Y, Savadogo A (2017) Évaluation des pratiques agricoles des légumes feuilles: le cas des utilisations des pesticides et des intrants chimiques sur les sites maraîchers de Ouagadougou, Burkina Faso. Journal of Applied Biosciences 117:1165811668

73. Traoré A. Haggblade S (2017) Mise en œuvre des politiques régionales sur les pesticides en Afrique de l'Ouest: rapport de l'étude de cas en guinée. Document de Travail 68. Août 2017

74. Traoré SK, Mamadou K, Dembélé A, Lafrance P, Mazellier P, Houénou P (2006) Contamination de l'eau souterraine par les pesticides en régions agricoles en Côte d'Ivoire (centre, sud et sud ouest). Journal Africain des Sciences de l'Environnement 1:1-9

75. Traoré A, Ahoussi KE, Aka N, Traoré A, Soro N (2015) Niveau de contamination par les pesticides des eaux des lagunes Aghien et Potou (Sued-Est de la Côte d'Ivoire). Int. J. Pure App. Biosci. 3 (4): 312-322 (2015). ISSN: 2320 7051

76. Torres AMR, O'Flaherty LM (1976) Influence des pesticides sur Chlorella, Chlorococcum, Stigeoclonium (Chlorophyceae), Tri-bonema, Vaucheria (Xanthophyccae) et Oscillatoria (Cyano-phyceae). Phycologia 15:25-36

77. Vernet R (1994) La préhistoire de la vallée de la Mékrou (Niger Méridional). In: Bulletin de la Société préhistorique française, tome 91, n³, 1994. pp. 200-208. DOI: https://doi.org/10.3406/bspf.1994.10506

78. WHO (1990) Public health impact of pesticides used in agriculture. Geneva

79. Zabeirou H, Guero Y, Tankari D, Haougui A, Basso A (2018) Farmer practices of using pesticides on vegetable crops in the department of Madaou; EWASH and journal volume $n$ 2018, 263-74. ISNN 2509-1069

\section{Figures}




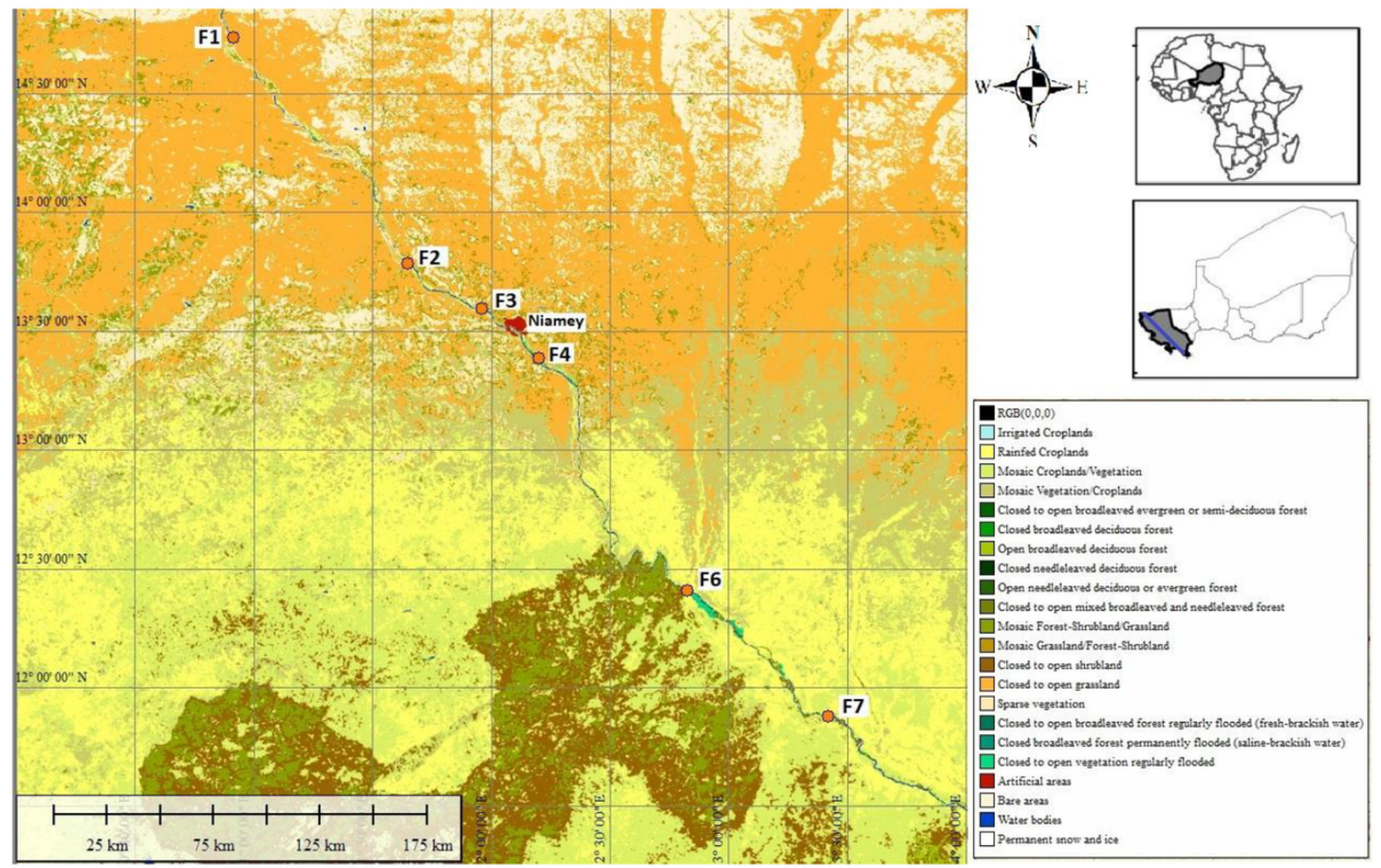

Figure 1

Location of the study area and sampling sites

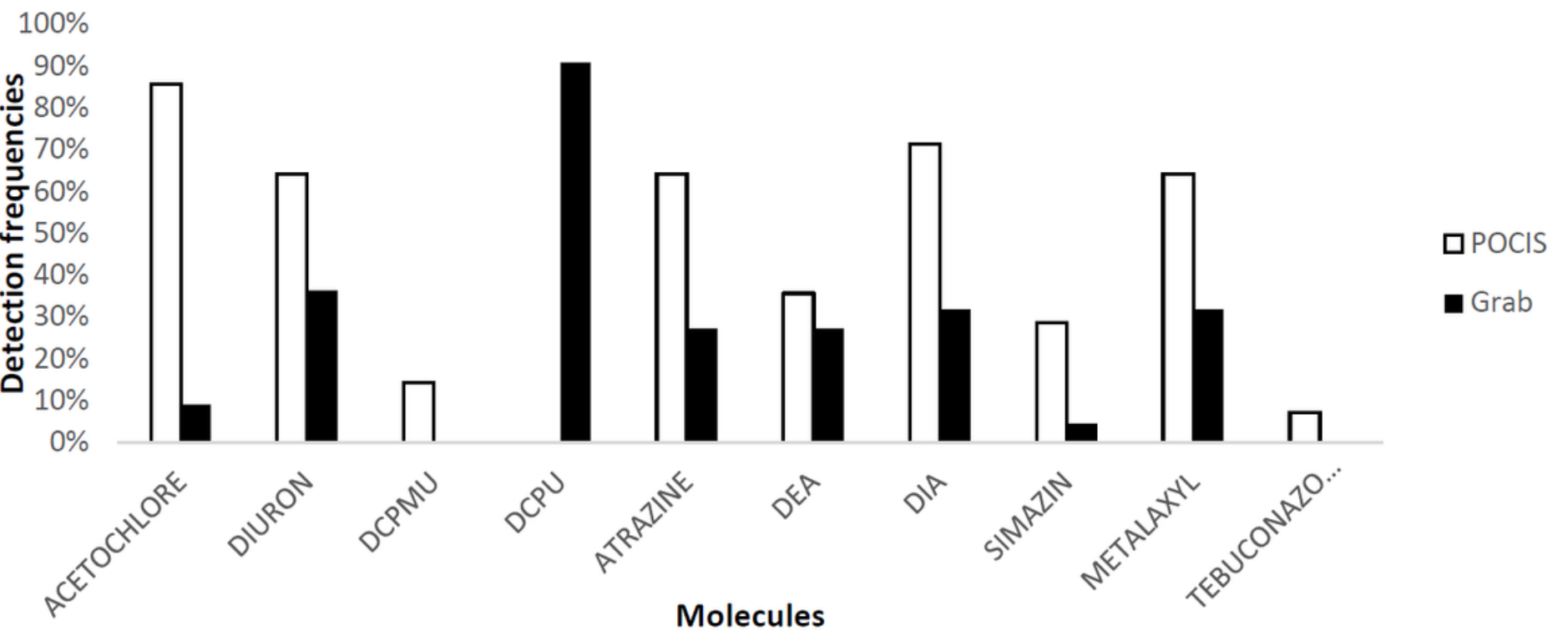

Figure 2 


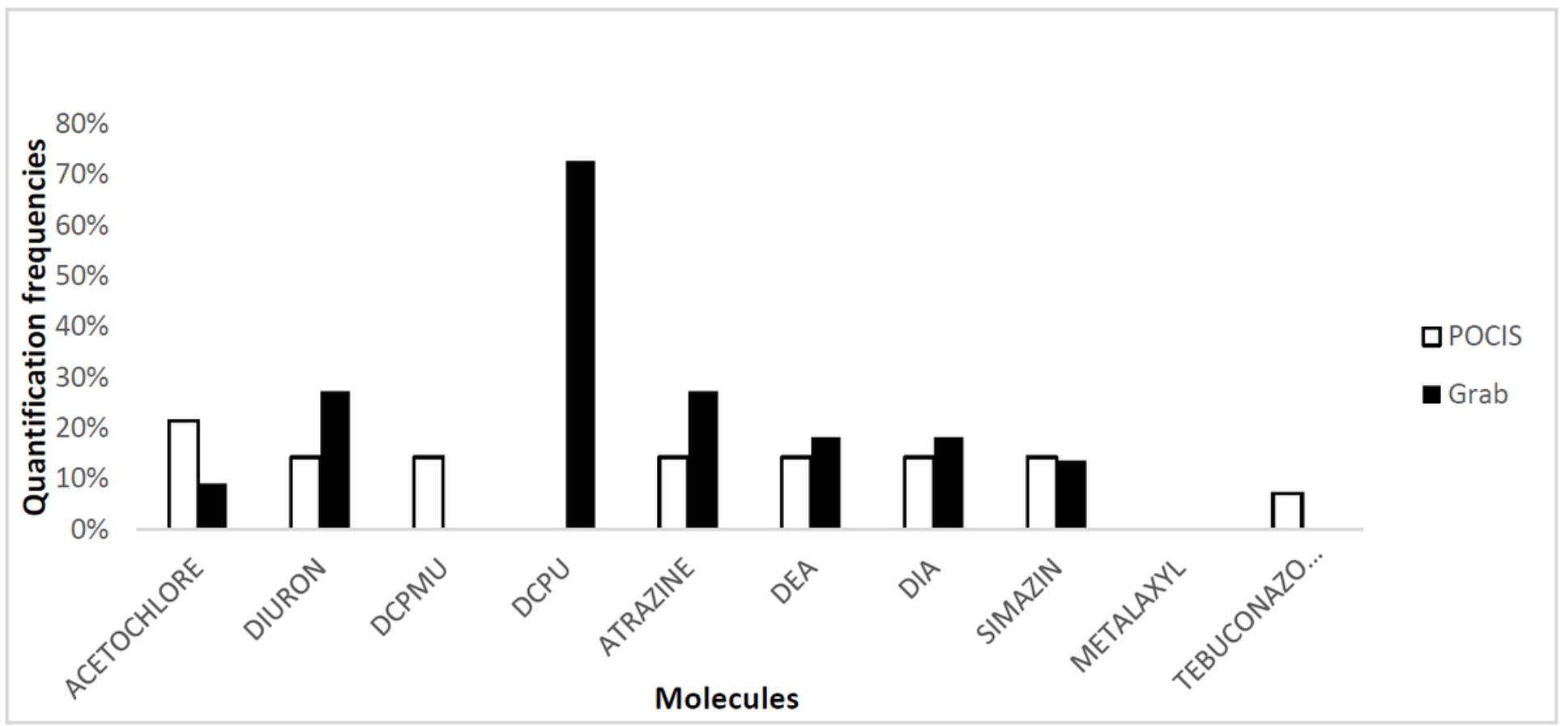

Figure 3

Quantification frequency of herbicides and fungicides in the study area

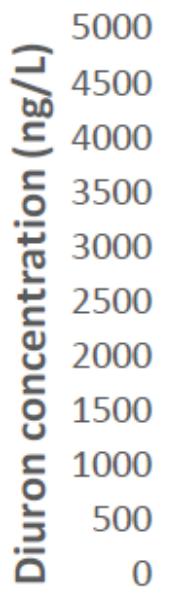

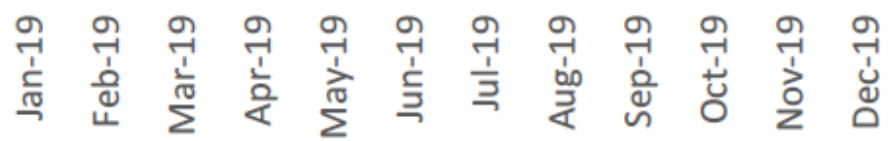

Months
0

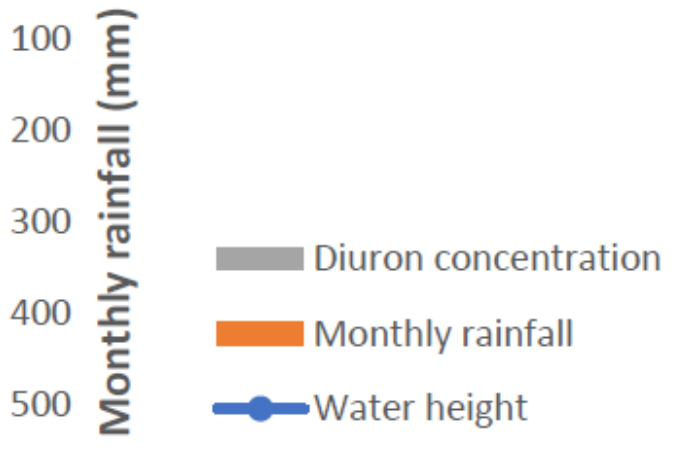

Figure 4

Concentration of diuron in relation to water depth and rainfall 


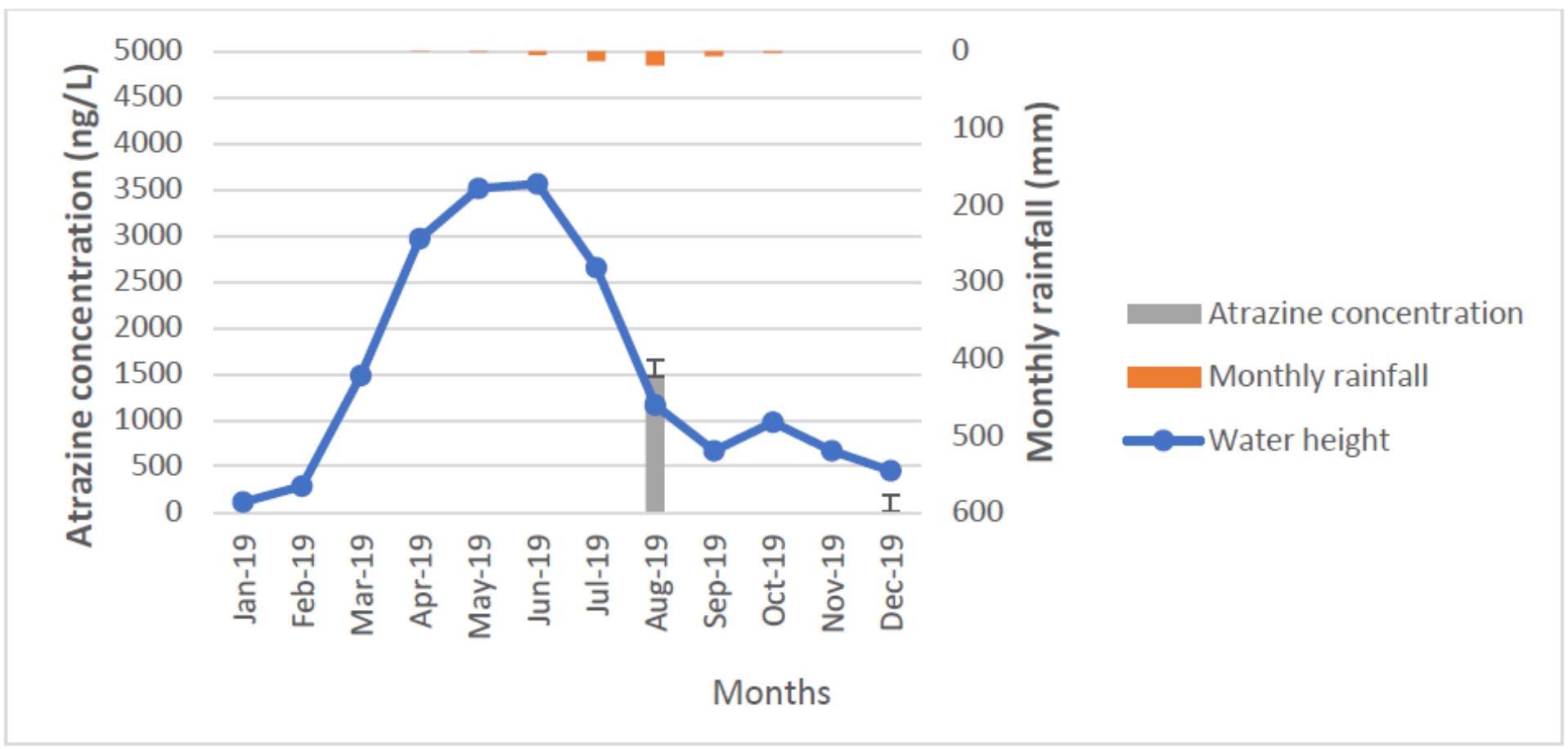

Figure 5

Concentration of Atrazine in Relation to Water Head and Rainfall 